\title{
Research Status and Roles of Natural Analogue Studies in the Radioactive Waste Disposal
}

\author{
방사성폐기물 처분에서 자연유사연구 역할 및 연구 동향
}

\author{
Min-Hoon Baik ${ }^{*}$, Tae-Jin Park ${ }^{1}$, In-Young Kim ${ }^{1}$ and Kyung-Woo Choi ${ }^{2}$ \\ ${ }^{1}$ Korea Atomic Energy Research Institute, 989-111 Daedeokdaero, Yuseong-gu, Daejeon, Korea \\ ${ }^{2}$ Korea Institute of Nuclear Safety, 62 Gwahakro, Yuseong-gu, Daejeon, Korea \\ 백민훈 ${ }^{*}$, 박태진 ${ }^{1}$, 김인영 ${ }^{1}$, 최경우 ${ }^{2}$ \\ 1 한국원자력연구원, 대전광역시 유성구 대덕대로 989 번길 111 \\ 2 한국원자력안전기술원, 대전광역시 유성구 과학로 62
}

(Received March 14, 2013 / Revised April 22, 2013 / Approved April 30, 2013)

Natural analogue studies play an important role in the safety case which requires multiple lines of evidence including the safety assessment for the geological disposal of radioactive wastes. In this study, foreign status of natural analogue studies was investigated by summarizing natural analogue results according to the research topics related with repository materials and radionuclide migration and retardation. Main results, issues, and applicability of the foreign natural analogue studies were also analyzed. The results of domestic natural analogue studies were classified into studies using uranium ore bodies, rocks, groundwaters, and archeological artifacts, respectively, and their main results were summarized. There are massive materials for natural analogue studies which have been carried out during last several decades but they have not been actively applied to the safety assessment and safety case development for the radioactive waster disposal. Thus, in this study, applicable methods of natural analogues were summarized and a methodology for improving their applicability was examined. Natural analogue study is apparently necessary to improve and illustrate the reliability of safety assessment for a radioactive waste repository. Therefore, it is necessary to develop a methodology and construct a natural analogue information database for the application of the results from natural analogue studies to safety case development.

Key words: Natural analogue study, Radioactive waste, Geological disposal, Safety assessment, Safety case

자연유사연구는 방사성폐기물의 지하 처분에서 안전성평가를 포함하는 다중의 안전성 확보를 요구하는 safety case에서 중 요한 역할을 담당하고 있다. 본 연구에서는 해외의 자연유사연구 동향을 조사하여, 처분장 재료물질들과 핵종이동 및 지연과 관련된 자연유사연구 결과들을 연구주제별로 정리하고, 주요 연구결과와 문제점, 결과의 활용성 등에 초점을 두고 분석하였 다. 아울러 국내에서 수행 된 자연유사연구 결과들을 우라늄 광상 연구, 암반을 이용한 연구, 지하수를 이용한 연구, 고고학적 유물을 이용한 연구 등으로 분류하고, 그 주요 결과들을 정리하였다. 지난 수 십 년 동안 수행되어 온 방대한 양의 자연유사 연구 결과들이 존재하지만, 처분안전성 평가와 safety case 개발에 적극적으로 활용되지 못하였다. 따라서 본 연구에서는 자 연유사연구 결과의 활용방법을 정리하고, 활용성을 증진하기 위한 방법론을 검토하였다. 방사성폐기물 처분장에 대한 안전 성 평가의 신뢰성을 증진하고 검증하기 위해서는 자연유사연구의 수행은 필수적이다. 따라서 자연유사연구 결과들을 safety case 개발에 활용하기 위해서는 자연유사 정보 데이터베이스의 구축과 함께 활용방법론이 개발되어야 할 필요가 있다.

중심단어 : 자연유사연구, 방사성폐기물, 지질 처분, 안전성평가, Safety case

*Corresponding Author. E-mail: mhbaik@kaeri.re.kr, Tel: +82.42.868.2089 


\section{1. 서 론}

자연유사연구(natural analogue study)는 방사성폐기 물 처분장 주변 환경과 어느 정도 유사성을 가진 자연 및 생태의 고고학적 또는 산업적 시스템을 조사하는 것이다. 그러나 모든 면에서 처분장과 일치하는 자연시스템은 없 기 때문에 완전한 유사연구는 불가능하다. 처분장의 구성 요소들 또는 처분장 변화를 제어하는 과정들과 유사성을 가진 많은 자연시스템들이 존재하고, 적절한 유사시스템 들을 잘 연구하면 단기적 및 장기적 처분장 거동에 대한 이 해와 안전성 평가모델링의 신뢰성을 향상하는데 매우 유 용하고 중요한 정보들을 얻을 수 있다[1, 2]. 자연유사연구 는 IAEA (International Atomic Energy Agency)에 의해 다 음과 같이 정의되고 있다[3]: “자연유사연구는 처분시스템 의 어떤 부분들에서 발생할 것으로 알려졌거나 예측되는 것들과 동일하거나 유사한 물질들, 조건들, 과정들의 자연 적 발생을 조사하는 유사적 접근이다. 따라서 자연유사물 들은 그들이 가진 고유한 물리화학적 특징들보다는 그들 을 연구하고 평가하는데 사용된 방법론들에 의해 더 잘 정 의된다".

자연유사연구들이 방사성폐기물 처분장에서 발생하 는 많은 과정들을 이해하는데 기초가 되고, 안전성평가 코 드를 개발하는데 중요한 역할을 수행하고 있다는 것에는 이견이 없다. 특히 처분 안전성평가에서 사용된 모델들과 자료들의 신뢰성을 평가하고 제공하는데 도움이 될 수 있
는 중요한 방법 중 하나가 자연유사연구를 수행하는 것이 다[4-6]. 최근에 전 세계적으로 처분안전성 확보를 위한 평 가프로그램이 정량적인 안전성평가를 넘어서 safety case 개념으로 확대되어 처분안전성과 관련된 보다 광범위하고 다중의 안전성 증거자료의 확보를 요구하고 있는 실정이 다. IAEA와 OECD/NEA 등에서는 처분 프로그램을 고려 하고 있는 나라에서는 처분 안전성의 신뢰성 확보를 위해 안전성평가를 포함하는 safety case를 개발하여 적용하기 를 권고하고 있다 $[7,8]$. 일반적으로 자연유사연구는 방사 성폐기물 처분장 폐쇄 후 안전성평가를 지원하는 처분장 의 장기거동에 대한 이해를 증진시키고, 안전성평가 모델 에 필요한 정량적 자료를 제공하고, 심지층 처분의 안전성 입증을 위한 보조적인 도구로 활용되고 있다[8]. 처분안전 성 평가에서 자연유사연구의 역할과 구성 요소와의 상관 관계를 Fig. 1 에 정리하여 도시하였다.

해외에서는 전 세계 우라늄 광 지역을 중심으로 다양 한 자연유사연구가 수행되어져 왔으며, 현재 국제기구를 중심으로 한 대규모의 자연유사연구는 수행되고 있지 않 지만, 처분안전성 확보 및 safety case 개발 차원에서 자국 의 상황에 필요한 다양한 자연유사연구를 수행하고 있다. 특히 전 세계의 관련 전문가들이 모여 각국의 자연유사연 구 현황과 정보들을 교환하는 모임인 Natural Analogue Working Group (NAWG)라는 국제단체를 EC (European Commission) 후원 하에 1985년에 결성하여 매 2-3 년 마 다 Workshop을 개최하고 있다[9]. 또한 EC (European

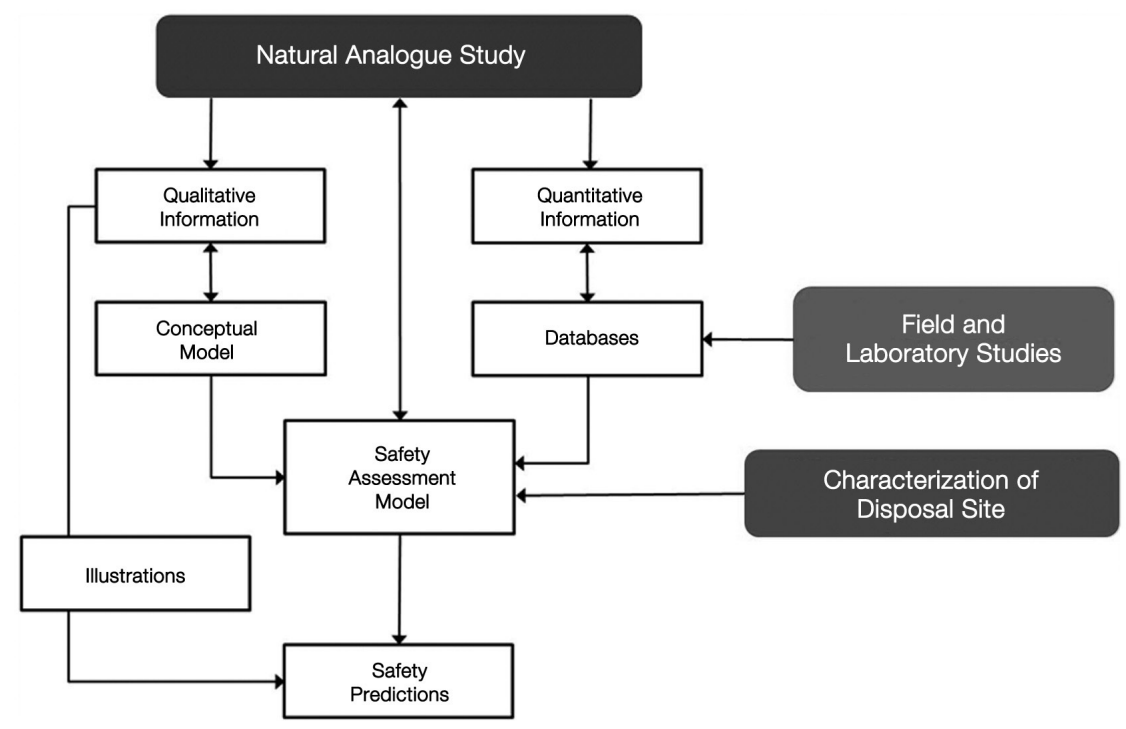

Fig. 1. Schematic diagram illustrating the relationships between natural analogue studies and the various components in the safety assessment of a disposal concept for radioacitve wastes [8]. 
Commission)에서 지원하는 제 5차 EURATOM FP 프로 그램의 일환으로 유럽 여러 국가들이 참여하는 처분 성능 및 안전성평가에서 자연유사연구 활용과 대중과의 의사소 통을 증진하기 위한 NAnet 공동연구를 2003-2004년에 걸 쳐 수행하였다[10]. 그러나 국내에서는 관련 연구의 수행 이 매우 미미한 수준이며, 최근에야 자연유사연구가 safety case 개발이나 안전성평가에서 보조적인 안전성지표로 고 려되어야 함을 인식하고 있는 실정이다.

따라서 국내에서도 자연유사연구의 본격적인 추진이 필요한 시기에 도달하였기에 먼저 국내 및 해외의 자연유 사연구 현황을 조사·분석하는 하는 일이 선행되어야 할 것이다. 이러한 필요성에 근거하여 본 논문에서는 방사성 폐기물 처분 관점에서 수행된 국내 및 해외의 자연유사연 구 현황을 인공방벽 재료물질들과 핵종이동과 지연과 관 련된 주요 연구 주제별로 조사·분석하고, 이들 주제들에 대한 자연유사 연구결과들의 역할과 향후 고려하고 해결 해야할 중요한 문제들에 대해서도 논의한다. 아울러 처분 안전성 평가 및 safety case 개발에서의 자연유사연구의 역 할과 활용방법에 대해서도 간략하게 검토하고 분석한다.

\section{2. 해외 자연유사연구 동향 분석}

해외에서의 자연유사연구는 자국의 처분프로그램에 의해 자체적인 연구수행도 있었지만, 대부분의 경우 IAEA 및 $\mathrm{OECD/NEA}$ 와 같은 국제기구의 지원 하에 대규모의 국 제공동연구 프로젝트로 수행되었다. 주요한 대규모 자연 유사연구 프로젝트는 다음과 같으며, 이들 프로젝트들에 대한 자세한 정보 및 연구내용은 다양한 문헌자료들[2, 4, $11,12]$ 에서 소개하고 있으므로 여기에서는 생략한다.

- 아프리카 가봉의 자연 핵분열 반응기인 Oklo site 프로젝트

· 브라질 Poços de Caldas 프로젝트(Osamu Utsumi 우라늄광과 Morro de Ferro 토륨/희토류광)

· 캐나다 Cigar Lake 우라늄광 프로젝트

· 호주 Alligator Rivers 우라늄광에서 수행 된 ARAP 및 ASARR 프로젝트

· 핀란드 Palmottu 프로젝트

· 멕시코 Peña Blanca 우라늄광 프로젝트

· 일본 Tono 우라늄광 연구

· 스페인 Mina Fe 우라늄광 프로젝트

· 아라비아만에 위치한 Oman 프로젝트
· 요르단의 Maqarin 프로젝트

· 스코틀랜드 Broubster 및 Needle's Eye 연구 프로 젝트

\section{1 처분장 재료물질들 대한 자연유사연구}

여기에서는 처분장의 공학적방벽에 해당하는 주요한 처분장 재료물질들의 성능에 대한 해외에서의 자연유사연 구 동향들을 주요 연구내용 및 연구결과들을 중심으로 간 략하게 기술하고, 자연유사 연구결과들의 역할과 향후 고 려하고 해결해야할 중요한 문제들에 대해서도 언급한다. 가상의 방사성폐기물 처분시스템에서의 재료물질들과 캐 나다 Cigar Lake 우라늄광 자연유사연구 부지와의 유사성 을 Fig. 2에 정리하여 나타내었다.

\subsection{1 붕규산염 유리}

붕규산염 유리는 일반적으로 많은 나라들의 처분개념 에서 사용후핵연료의 재처리로부터 생산된 고준위폐기물 을 고정화하는 물질로 제안되어져 왔다. 처분장 조건에서 붕규산염 유리의 거동과 관련해서 많은 자연유사연구 결 과들이 존재하는데, 이들 연구들은 주로 천연 유리를 붕규 산염 유리의 유사물로 생각하여 용해율(dissolution rate) 과 변형생성물(alteration product)을 측정하는 연구를 수 행하였다[13, 14].

일반적으로 붕소는 유리고화체의 주요 성분으로 실리 카 함량을 감소시켜서 점도와 용융점을 낮추고, 조작을 용이하게 한다. 붕규산염 유리의 상대적으로 낮은 실리 카 함량(통상 50-60\%)으로 인해 유문암질 유리(rhyolitic glass) 또는 텍타이트(tektites) 보다 현무암질 유리(basaltic glass)가 붕규산염 유리의 자연유사물에 더 가깝다. Chapman 등은 유리의 저유리화(devitrification) 및 침출 과 관련된 주요 자연유사연구 결과들을 정리하였는데, 저 유리화는 온도가 너무 높지 않다는 가정 하에서 처분장 안전성 고려 기간 동안에는 큰 문제가 되지 않을 것이고, 심지층 처분의 지하수에서 유리고화체의 수명은 $10^{7}$ 에서 $10^{8}$ 년 수준이 될 것 이라고 보고하였다[5]. 아울러 Miller 등은 자연유사연구 결과 해석에서 천연유리와 붕규산염 유리의 화학적 차이점이 중요하게 고려되어야 하고, 방사 성 핵종들의 유리 변형생성물 상으로의 혼입(incorporation)이 고려해야할 중요한 과정이라고 보고하였다[11]. 특히, 고고학적 유리들에 대한 조사결과는 천연유리에서 발생하기 어려운 과정들에 의해 유리가 분해될 수 있음을 

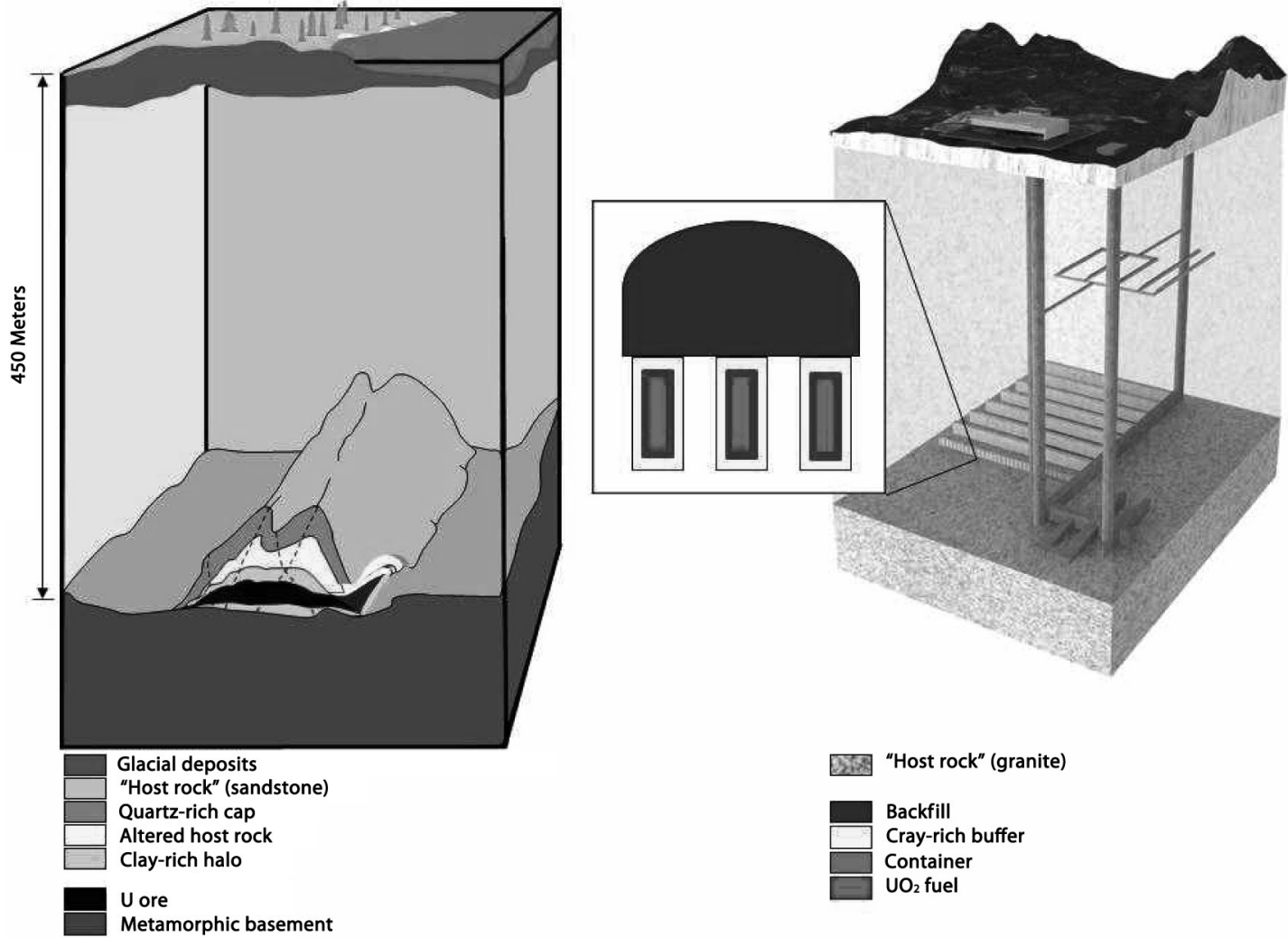

Fig. 2. Close analogies of the repository materails and system structure to the natural analogue study site, Cigar Lake uranium deposit, Canada.

보여주는데, 이것은 불포화 처분장 개념(예를 들면, Yucca Mountain 처분장)에서는 중요한 문제가 될 수 있지만 포 화 처분장 개념에서는 그렇지 않다[11].

\subsection{2 사용후핵연료}

사용후핵연료에 대한 훌륭한 자연유사물은 자연적으 로 발생하는 우라늄 광물인 우라니나이트(uraninite)가 대 부분이고, 그 다음으로는 역청 우라늄광(pitchblend)이다. 아프리카 가봉에 위치하는 Oklo 우라늄광은 사용후핵연 료 용해과정을 연구하는데 가장 이상적인 자연유사물이라 할 수 있고, 악틴족과 핵분열생성물들을 포함하고 있는 내 부 결정상들을 현미경학적으로 잘 조사하면 유용한 정보 들을 얻을 수 있다[5]. 그리고 캐나다의 Cigar Lake 우라늄 광도 사용후핵연료의 거동을 연구할 수 있는 훌륭한 자연 유사물이라 할 수 있다[15]. 사용후핵연료와 관련한 자연 유사연구들은 주로 우라늄광물들의 용해 및 $\mathrm{UO}_{2}$ 로부터 방 사성핵종들의 유출과 관련된 연구들[15-17] 그리고 $\mathrm{UO}_{2}$ 용 해생성물들에 대한 연구들 $[16,18]$ 이 대부분이다. 아울러 이러한 연구들과 함께 Oklo 우라늄광에서 $\mathrm{UO}_{2}$ 용해가 방
사성핵종들의 거동에 미치는 영향에 대한 연구들도 함께 수행되었다[19].

최근에는 우라늄 광물에 대한 광물학적, 지구화학적 연구들이 많이 수행 되었으며[20], 이러한 연구들은 사용 후핵연료 및 고준위폐기물의 장기거동을 평가하는데 유용 한 정보를 제공한다. 특히, 스페인의 Mina Fe 자연유사연 구 부지에서는 사용후핵연료의 용출에 의한 우라늄의 지 구화학적 반응에 대한 연구를 중점적으로 수행하였다[21]. 일본 Tono 우라늄광에서는 우라늄광으로 부터 얻은 수리 화학적 및 광물학적 자료를 이용하여 용해도 제한 유출 개 념에 대한 검증을 실시하였는데, $\mathrm{UO}_{2}(\mathrm{am})$ 용해도에 의해 제어되는 우라늄의 유출농도는 지화학적 환경 $(\mathrm{Eh}, \mathrm{pH}$, 탄 산염 농도 등)에 의존하며 $10^{-6.1}-10^{-8.7} \mathrm{~mol} / \mathrm{kg}$ 의 범위를 가 지는 것으로 계산되었다[22].

이러한 연구결과들을 종합해보면 타당한 처분장의 지 질학적 조건들에서 즉, 온도와 지하수 유동이 낮고 우라늄 의 산화가 $\mathrm{U}_{3} \mathrm{O}_{7}$ 이상으로 진행되지 않을 때, 우라니나이트 의 용해율은 매우 느리고, 비록 높은 방사능 준위의 장기적 인 영향에 대해서는 여전히 불확실성이 높지만, 사용후핵 
연료는 상당히 긴 시간동안 지속성을 보일 것이라고 보고 하고 있다. 사용후핵연료의 부식 거동 및 부식생성물의 특 성과 반응성을 이해하는 것은 처분시스템의 성능평가 모 델링을 위해서나 또는 자연유사연구 결과해석에서도 매우 중요하다. 자연유사연구는 사용후핵연료 부식에 대한 다 른 모델 형태들(즉, 침출과 산화적부식)을 시험하는데도 기여할 것이다. 특히, 처분장과 유사한 조건들에서의 우라 니나이트 부식에 대한 자연유사연구 결과들은 관련 실험 들에 매우 유용한 정보를 제공할 것이다.

\subsection{3 금속}

방사성폐기물 처분시스템에서 주로 사용되는 금속 재 료는 주로 구리, 주철 및 강철과 같은 금속들이다. 구리에 대한 자연유사연구는 주로 구리의 내구성(durability)와 지 속성(longevity)에 초점을 두고 수행되었다. 그러나 구리 는 대규모의 광범위한 광물상으로는 형성되지 않기 때문 에 약간은 제한적이라 하겠다[23]. 구리의 부식률을 정량 적으로 결정하기 위한 노력들이 많은 고고학적 유물들을 이용하여 수행 되었다[24]. 특히, 스웨덴의 KBS-3 성능평가 를 위해 고고학적 유물들을 이용한 구리에서의 피팅인자( 피팅깊이와 평균부식률의 비)가 결정되기도 하였는데, 사 용된 구리 및 구리 합금 물질들은 로마 동전과 꽃병, 스웨 덴 청동기 시대의 물건들, 17 세기 동전과 구리덩어리 등이 었다[25]. 측정된 피팅인자는 3보다 작게 나타났는데 이는 KBS-3에서 사용한 피팅인자 값인 25보다 확실히 보수적 인 값이다. 구리부식에서 자주 언급되는 다른 유사물은 스 웨덴 Kronan 난파선의 잔해로부터 나온 대포인데, KBS-3 사용후핵연료 처분 설계에 사용된 구리용기의 유사물로 이용되기도 하였다[26].

구리부식에 대한 자연유사연구 결과들로부터 구리는 처분장에서 예상되는 조건들에서 매우 안정적이며, 균일 부식률(uniform corrosion rate)은 0.03 과 $1 \mu \mathrm{m}$ 사이로 KBS-3에서 제안된 $10 \mathrm{~cm}$ 정도 두께의 구리 처분용기의 경 우엔 수 십 만년에서 수 백 만년 정도의 수명을 가질 것이 라는 사실이다[11]. 아울러 구리 부식생성물의 특성과 반 응성을 결정하는 것도 구리 부식연구에서 매우 중요한데 타당한 처분장 조건에 부합하는 고고학적 유물들에 대한 자료는 부족한 상태이다. 최근에는 고고학적 유물들을 이 용하여 혐기성 환경에서 철의 부식에 의한 구리용기의 부 피증가가 처분장 공학적방벽 설계에 미치는 영향에 대한 자연유사연구를 수행하였는데, 연구 결과 거의 영향이 없 는 것으로 나타났다[27].
철에 대한 대부분의 자연유사연구들은 고고학적 유물 들[28] 및 산업적 유물들[29]을 이용한 철의 부식과 관련된 연구들이고, 일부 연구들은 철 운석을 이용하여 수행되었 다[28]. 철 부식에 대한 자연유사연구는 그리 많지 않고, 운 석을 이용한 연구는 Ni-Ge 합금의 부식거동에 대한 모호 하고 불충분한 정보를 제공하기 때문에 신뢰성이 떨어진 다. 철 부식의 고고학적 유사물들은 다양한 환경에서 철 부 식률에 대한 정보를 제공하는데 대부분의 자료들은 철 부 식이 250,000 300,000 년 정도가 걸리는 것으로 나타났 다. 고고학적 유물을 이용한 연구로 스코틀랜드 Inchtuthil 에 있는 로마군단 요새에서 발견된 철 못들의 부식률은 작 은 값을 나타내었다[11]. 모든 철 못들의 표면은 부식되었 지만 부식의 정도는 저장고에서의 위치에 따라 달랐는데 저장고의 바깥쪽은 산화환경에 의해 부식이 많이 되었고, 안쪽은 2,000 년 동안 거의 부식이 일어나지 않았는데 이 것은 처분 환경에서의 철 처분용기의 부식에 대한 중요한 자연유사적 정보를 제공하는 것으로 간주된다.

처분장에서 강철 처분용기가 부식할 때, 처분용기는 고체 반응생성물로 코팅될 것이고, 큰 부피의 수소가 발생 될 것이다[11]. 이러한 다량의 수소발생은 처분장의 공학 적방벽과 암반에 구조적 손상을 유발할 것이다. 또한 철의 부식생성물들은 핵종들을 수착하고 산화환원 전위를 완충 하기 때문에 처분장 안전성 측면에서도 매우 중요하다. 예 를 들면, Poços de Caldas의 우라늄광에서 추적자 원소들 이 비정질의 철 옥시수산화물(oxyhydroxide) 상들에 수착 되어 redox front에 침적됨을 보여주었다[30]. 철과 강철의 부식생성물의 반응성은 처분장 근계 영역의 성능에서 매 우 중요하다. 특히, 환원환경에서 철 부식생성물의 핵종거 동 영향을 평가하는 것은 매우 중요한데 이를 위한 추가적 인 자연유사연구의 수행이 필요하다.

\subsection{4 벤토나이트}

벤토나이트는 고준위폐기물 처분장의 완충재 또는 중 - 저준위폐기물 처분장 사일로 뒷채움재 등으로 사용 되는 수착성, 팽윤성, 차수성이 뛰어난 점토물질이다. 벤 토나이트에 대한 자연유사연구는 이전부터 벤토나이트의 일라이트로의 변질, 물리화학적 특성 변화, 처분장의 주 변 물질인 처분용기 및 뒷채움재와의 반응성 등에 대한 주 제들을 중심으로 수행되었다. 벤토나이트의 변질에 대한 자연유사연구는 연구 초기에는 주로 미국의 Gulf 영역과 스웨 덴 지역에서에서 속성작용(diagenetic)의 일라이트화 (illitization)에 대해 수행되었다[31, 32]. 그러나 이러한 연 
구들은 가열 시간이 고준위폐기물 처분장에서 고려하는 시간보다 몇 차수가 더 길기 때문에 실제 처분장 환경과 는 매우 달랐다. 자연환경에서 일라이트화 속도는 속도론 적 모델에서 예측된 것보다 상당히 느린 것으로 나타났는 데 이것은 포타슘 $(\mathrm{K})$ 의 느린 공급 속도에 기인하는 것으로 보고되었다[33].

아울러 몇몇 자연유사연구들에서 접촉변성적(contact metamorphic) 일라이트화에 대한 연구가 수행되었다[32, 34, 35]. 그러나 이러한 연구들의 온도 조건은 처분장에 서 예상되는 온도보다 훨씬 높은 $900^{\circ} \mathrm{C}$ 까지 도달하는 온 도라 실제 처분장 환경과는 매우 상이하였다. 중 · 저준위 방사성페기물 처분장에서 지하수가 대용량의 시멘트를 침 출할 때 높은 농도의 포타슘 농도가 발생하기 때문에 벤 토나이트의 변질은 고준위폐기물 처분에서 보다 더 큰 문 제가 될 수 있다. 최근에 스페인의 Morrón de Mateo 벤 토나이트 광산에서 자연유사연구의 일환으로 고준위폐기 물 지하 처분장의 벤토나이트 방벽에 대한 열적 지구화학 적 영향에 대한 연구가 수행되었다[36, 37]. 연구결과들은 Morrón de Mateo 벤토나이트 광산이 벤토나이트의 열적 화학적 변질을 연구할 수 있는 좋은 자연유사 연구부지임 을 보여 주었다.

만약 처분용기가 주변 벤토나이트를 통해 침하되어 처 분공이나 터널 바닥에 놓이게 되면 벤토나이트의 성능에 이상이 올 것이다. 처분용기 침하는 실험실적 실험과[38] Stripa 광에서의 대규모 실험을[39] 통해 수행되었다. 두 실 험들에서 비록 관심을 가질만한 규모는 아니었지만 관측 가능한 처분용기의 이동이 관측되었다. 그러나 이러한 실 험들은 실제 크기의 처분용기를 이용하여 수행된 것도 아 니고, 3-4년의 짧은 기간에 걸쳐 수행된 것이기 때문에 실 제 처분 조건과는 차이가 있다. 처분용기의 침하에 대한 자연유사연구는 지금까지 거의 수행된 바가 없으므로 추 가적인 연구가 수행될 필요가 있으며, 중국 등에서 발견되 는 점토가 깔린 매장된 침실 등의 고고학적 환경이 이러한 문제에 대한 자연유사물이 될 수 있을 것이다. 벤토나이 트 완충재와 다른 처분장 물질과의 상호작용 또한 고려되 어야 할 중요한 문제이다. 특히 처분용기로부터 침출된 구 리나 철 이온들이 벤토나이트와 양이온 교환을 통해 벤토 나이트 격리 성능의 저하를 유발할 수 있을 것이다[40]. 따 라서 이러한 구리 처분용기와의 상호작용에 대한, 특히 상 호작용에 기인하는 광물학적 변화에 대한 자연유사연구도 필요할 것이다. 철 처분용기의 경우에는 위의 반응이 발생 함을 나타내는 몇 개의 실적적인 연구들이 수행되었다[41].
벤토나이트의 수력학적 방벽으로써의 기능과 관련된 자연유사연구의 하나로 점토 환경에서 보존되어온 유기 물질에 대한 몇 가지의 예들이 존재한다. 예를 들면, 이 태리 Dunarobba 에 있는 1.5 백만 년 된 화석숲이다[34]. Dunaroba의 화석숲은 다른 매장된 숲들과는 달리 여전히 원래의 위치에 있고, 나무들도 여전히 목재로 구성되어 있 다는 점이 매우 훙미롭다. 일반적 환경이라면 목재들은 갈 탄(lignite)으로 변하고 결국엔 석화될 것인데, Dunaroba 의 화석숲의 나무들은 점토환경에 둘러싸여 있었기에 열 화과정으로부터 보호받을 수 있었다. 특히, 목재가 중 - 저 준위 방사성폐기물에 함유되어 있는 유기물이나 셀룰로오 스 물질과 유사하기 때문에 이 부지는 특히 중 - 저준위 방 사성폐기물처분장에 타당한 조건이라고 하겠다. 그리고 중국에서 발견된 2100 년 된 송장과 매장물들 또한 점토의 격리 성능을 잘 보여준다[42]. 점토층이 매장실의 산소가 모두 소모될 때까지 효과적으로 공기를 차단하고 시체의 부패를 방지하였다. 처분안전성에서 압축벤토나이트의 중 요한 역할중 하나는 콜로이드성 및 고분자성 물질들을 여 과하는 것이다. 실험실적 연구들은 이미 오래전에 압축된 벤토나이트의 기공이 너무 작아서 콜로이드의 이동을 허 용하지 않거나 유동성이 매우 느리다는 것을 보여주었다 [43]. 아울러 캐나다 Cigar Lake 부지에서의 자연유사연구 는 점토들이 효과적인 콜로이드 여과제로 작용한다는 것 을 보여주었다[44].

\subsection{5 시멘트 및 콘크리트}

방사성폐기물 처분에 있어 콘크리트와 시멘트는 매우 중요한 역할을 수행한다. 특히 중·저준위 방사성폐기물 처분과 관련한 주요 역할은 물리적 지지와 억제 그리고 화 학적 억제라 할 수 있다. 시멘트 및 콘크리트와 관련한 자 연유사연구에는 크게 두 가지 접근법이 있다. 첫 번째는 고고학적 건물 시멘트(수백에서 수천 년 된)와 산업적 건 설 시멘트(수십에서 수백 년 된)를 연구하는 것이고, 두 번 째는 포틀랜드 시멘트의 수화(hydration) 과정 동안 발견 되는 화합물들과 유사한 광물들의 자연적 발생을 연구하 는 것이다[11]. 그러나 이러한 두 접근법은 실제 처분장 환 경과는 다른 환경에서 수행된 것이므로 완벽한 자연유사 정보를 제공하지는 못한다. 고대의 석회 콘크리트와 시멘 트들의 화학적 특성과 광물들을 결정하고 물리적 특성 등 을 시험하기 위한 연구들이 수행되었다[45, 46]. 고고학적 물질들은 시멘트의 CSH (calcium silicate hydrate) 화합물 들이 수천 년 동안 안정적으로 유지됨을 보여주었다. 아울 
러 포틀랜드 시멘트로 만든 콘크리트의 내구성에 대한 연 구들도 수행되었는데[35, 47, 48], 포틀랜드 시멘트의 CSH 화합물이 190 년 동안의 환경변화에도 충분히 안정적임 을 보여주었다.

심지층 처분환경에 다량의(약 $10^{6} \sim 10^{7}$ 톤) 콘크리트 및 시멘트를 사용하는 것은 현장 지화학적 조건에 큰 교란을 가져올 것이다. 오래된 시멘트 구조물들에 대한 자연유사 연구는 포틀랜드 시멘트의 역사가 오래되지 않았기 때문 에 특별히 유용하지는 않지만, 자연발생적인 고알칼리성 지하수의 진화를 조사하는 자연유사연구들이 Oman[49]과 Jordan[50] 자연유사연구 프로젝트들에서 수행되었다. 콘 크리트와 시멘트에 대한 자연유사연구는 아직 많은 연구 가 필요한 분야이며, 암반 등 다른 물질과의 상호작용, 핵 종 수착특성에 미치는 영향, 콜로이드 생성 및 여과 특성, 가스와 물 투과성, $\mathrm{CSH}$ 화합물의 결합 특성 등에 대한 추 가적인 연구가 필요하다.

\section{2 핵종이동 및 지연에 대한 자연유사연구}

여기에서는 처분장 인공방벽 및 천연방벽에서의 핵종 이동 및 지연과 관련된 중요한 과정들에 대한 자연유사연 구 내용들과 주요 결과들을 정리하고, 자연유사연구 결과 들의 역할과 향후 고려하고 해결해야할 중요한 문제들에 대해서도 논의한다. 가상의 우라늄광 자연유사연구 부지 에서의 지하매질을 통한 핵종들의 이동 및 지연과정을 Fig. 3 에 나타내었다.

\subsection{1 용해도 및 화학종}

용해도와 화학종에 대한 자연유사연구들은 크게 지화 학모델들을 이용한 모사 연구(simulation studies)와 블라 인드(blind) 모델링을 이용한 예측 실행(prediction exercises)과 같이 두가지 종류로 분류할 수 있다. 모사 연구 적 접근방법은 스코틀랜드의 Broubser 부지와 Needle's Eye 부지, 영국의 South Terras 부지, 호주의 Alligator Rivers 부지, 브라질의 Poços de Caldas 부지 등에서 수행되 었다. 스코틀랜드 Broubser 부지에서는 PHREEQC 지화 학코드와 CHEMVAL Stage 2 역역학 자료들을 이용하여 우라늄과 토륨의 관측된 거동을 성공적으로 모사하였다 [51]. 스크틀랜드 Needle's Eye 부지에서는 CHEMTRAD 복합 지화학 이동 코드를 이용한 모델링을 수행하여 우라 늄의 분포는 수착보다는 침전물에서 $\mathrm{U}^{4+}$ 상들의 침전에 의
한 것임을 지화학 코드들을 이용하여 모사하였다[52]. 영 국의 South Terras 부지에서는 PHREEQC 지화학코드와 CHEMVAL Stage 2 열역학 데이터베이스를 이용하여 Eh, $\mathrm{pH}$, phosphate, carbonate, 유기농도 들의 함수로 침전 물에서의 용해도와 화학종을 모델링 하였다[53]. 호주의 Alligator Rivers 부지에서는 부지특성화 작업 동안 부지 에서 관측된 지화학 조건들을 모사하기 위해 열역학 코드 들을 이용하였고, 현재 지하수의 화학종과 포화도를 평가 하고, 지하수 조건이 광물들이 형성될 때는 어떠했는지를 현재의 조건들을 이용하여 예측하였다[54]. 브라질 PoçOS de Caldas 부지에서는 redox front의 발달을 모사하기 위 하여 복합 코드들이 사용되었고 redox front에서 우라늄 의 광물화가 고려되었는데, 예측된 것은 관측된 역청 우라 늄광이 아닌 우라니나이트의 형성이었지만, redox front 의 환원쪽에서 국부화된 우라늄의 침전을 성공적으로 모 사하였다[55].

아울러 활발한 블라인드 모델링 접근방법이 Oman, Maqarin, Poços de Caldas, Cigar Lake 등과 같은 자연 유사연구들에서 수행되었다. Oman 부지에서 수행된 연 구는 2 단계 작업으로 수행되었는데 1단계에서는 초알칼 린 우물에서 현장 시료 채취 및 분석 전에 미량원소(trace element)들의 농도를 예측하는 것이었고, 2 단계에서는 5 개 샘물에서 채취한 지하수들을 분석하고 2 개의 열역학 적 코드들을 이용하여 블라인드 모델링을 수행하였다[48]. 즉, 2 개의 다른 데이터베이스로 우라늄과 토륨에 대해서는 MINEQL로, Ni, Pd, Se, Sn, Zn 등에 대해서는 PHREEQE 로 계산을 수행하였다. 계산 결과, 일반적으로 PHREEQE 로 수행한 금속들에 대한 모델링이 더 타당하게 보수적인 것으로 입증되었다. 시멘트성 처분장의 훌륭한 유사물로 알려져 있는 요르단의 Maqarin 부지에서는 시스템을 모사 하기 위해 PHREEQE 지화학코드를 이용하여 각기 다른 국 가들의 방사성폐기물 관리 프로그램에서 사용된 몇 종류 의 열역학적 데이터베이스를 이용하여 계산을 수행하였다 [50]. 고려된 원소들은 $\mathrm{U}, \mathrm{Th}, \mathrm{Ra}, \mathrm{Pb}, \mathrm{Se}, \mathrm{Ni}, \mathrm{Sn}, \mathrm{Cr}$ 등이 었는데, 우라늄을 제외하고 관측된 원소들의 농도는 $10^{2}$ $\sim 10^{3}$ 배 정도 코드 예측보다 작았기 때문에 더 정확한 예 측을 위해서는 처분장 조건에 타당한 환경에서 핵종 고체 상들에 대한 보다 정확한 열역학데이터의 제공이 필요하 다고 제안하였다.

브라질 Poços de Caldas 자연유사연구는 Chapman 등 에 의해 잘 검토되었고[56], 모델링 수행 결과는 Bruno 등 에 의해 제시되고 논의되었다[57]. 이 연구에서는 Osamu 


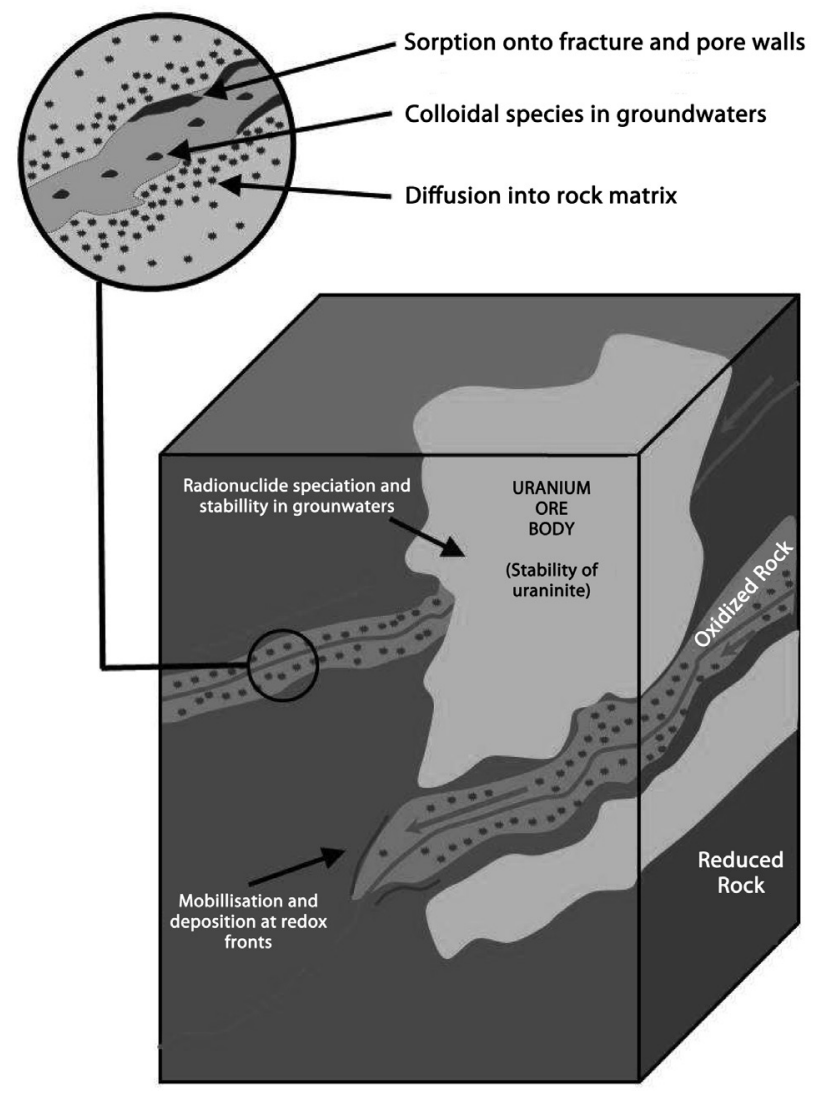

Fig. 3. Radionuclide migration and retardation processes considered in a supposed natural analogue study site of uranium orebody.

Utsumi 광과 Morro do Ferro로 부터 얻은 잘 분석된 3개의 시추공 지하수 조성들이 사용되었고, 블라인드 시험으로 참여한 기관들은 방사성폐기물 처분에 적합한 몇 개의 원 소들 $(\mathrm{U}, \mathrm{Th}, \mathrm{Pb}, \mathrm{Sr}, \mathrm{Ni}$ 등)에 대한 용해도, 화학종, 용해도 제한상(solubility limiting solid phase) 들을 계산하였다 [58]. 일반적으로 참여하는 기관들의 계산 결과들이 유사 하였고, 측정된 지화학 자료들과도 상당히 일치하였다. 캐 나다 Cigar Lake 부지에서는 ZZ-Hatches (Ver. 3.0) 열역 학적 데이터베이스와 PHREEQE 지화학코드를 이용하여 블라인드 예측 모델링 작업이 수행되었으며, 표준지하수 시료들에 대한 예측된 용해도와 측정된 지하수 미량원소 들의 농도를 비교하였다[11]. 전반적으로, 특히 적당한 열 역학적 데이터베이스가 존재하는 원소들( $\mathrm{Ba}, \mathrm{Co}, \mathrm{Th}, \mathrm{Zn}$ 등)에 대해서는 상당히 일치하는 결과를 보여주었다. 이것 은 Cigar Lake에서 이러한 원소들의 거동을 묘사하는데 평 형적 접근이 유용하다는 것을 보여주는 것이며, 사용후핵 연료 처분장 근계(near-field)의 성능평가에 평형적 접근이 타당함을 나타내는 것이라 하겠다. 아울러 Cigar Lake 우 라늄 광에서 근계 영역에서 우라늄의 유출 모델이 헬륨 유
출 자료를 이용하여 검증되고 다양한 화학종의 유출과 이 동에 대한 연구가 수행되었는데, 모델에 의해 계산된 우라 늄의 유출은 현장자료에 의해 관측된 바와 같이 매우 낮은 것으로 예측되었다[59].

이러한 핵종의 용해도 및 화학종에 대한 자연유사연구 들은 좀 더 엄격한 블라인드 모델링 시험에 초점을 둔 연 구들이 수행되어야 할 필요가 있으며, 현장 화학종 규명기 술의 개발 및 적용을 위한 연구들과 함께 데이터베이스와 지화학코드 사이의 간격을 좁히기 위한 노력이 더 필요하 다. 블라인드 예측 접근법은 성능평가에서 예측되는 방법 에 대한 훌륭한 추정이 되고, 모사적 접근법은 모델을 개발 하고 코드와 데이터베이스를 검증하는 것으로 지화학코드 의 적용 경험을 쌓는데는 가치가 있으나 성능평가 방법론 의 엄격한 시험은 되지 못하고 있는 실정이다.

\subsection{2 수착 및 지연}

핵종이동 동안의 지연과정은 자연유사연구에 의해 조 사되어진 최초의 메커니즘들 중의 하나이다. 단열 결정질 암반을 통한 핵종이동의 주요 메커니즘은 단열망 내의 수 
력학적으로 활성인 단열을 통한 이류현상이다. 이러한 활 성 단열들은 암석의 수화적 또는 열수적 변질에 의해 형성 된 이차광물들로 코팅되어 있다[60]. 특히 변질이 많이 된 단열들에서 이러한 광물들은 암반확산이 일어날 수 있는 고기공성 구역을 이루게 된다. 그러나 많은 경우에 안전성 평가를 목적으로 한 정량적 정보를 도출하는데 충분한 자 료들이 제공되지 않았으며, 정성적인 연구로 수행된 대표 적인 것이 Klipperås[60]와 Palmottu[61] 연구들이다. 일반 적으로 이러한 연구들의 대부분은 재유동화된 원소들의 철이 풍부한 고체상들(원칙적으로 이차 철수산화물들)과 의 결합에 관한 내용들이다 $[62,63]$. 예를 들면, 스페인의 화강암반 자연유사연구 부지인 El Berrocal 부지에서 수행 된 결과에 의하면, 석영, 장석, 점토광물, 탄산염 및 철 옥 시수산화물로 구성된 단열충전광물에 대한 우라늄과 토륨 의 수착은 화강암에 각각 2 배와 3 배 높은 것으로 나타났다 [63]. 그리고 핀란드 Palmottu 부지에서 수행된 연구에 의 하면, 단열 충전광물에서의 우라늄 농도(400 ppm)가 모 암에서의 농도(18-100 ppm) 보다 훨씬 높은 것으로 나타 났다[64]. Palmottu 부지에서 수행된 다른 연구에서는 우 라늄의 유동성은 지하수 순환의 변화와 관련이 되어있지 만 우라늄의 분산은 우라늄 광 주변 수 미터 내에 제한됨 을 확인되었다[65].

몇몇 자연유사연구들이 단열 표면에 대한 수착과 침전 의 영향을 설명하였지만 이러한 과정들을 명확하게 구분 하지는 못했고, 자연수에서 미량원소들의 이동 지연에 대 한 정량적인 정보를 제공하지도 못하였다. 이러한 자연유 사연구는 용질과 암석 표면과의 상호작용에 대한 유용한 관측 정보를 제공하고 어떤 고체상들이 중요한지에 대한 정보를 제공하지만 성능평가에 요구되는 수착자료들을 제 공하지는 못하였다. 스페인 Mina Fe 연구부지에서 우라늄 의 암반 균열에 의한 지연특성 규명 연구가 수행되어 핵종 지연 메커니즘에 대한 정보를 제공하였다[66, 67]. Mina $\mathrm{Fe}$ 와 같이 단열이 많고 풍화가 많이 된 부지에서 조차도, 비록 우라늄의 지연이 열린 단열들에서 발생하였지만 많 은 수의 단열들이 우라늄의 이동에 기여하지 못하였다. 아 울러 이동 지연은 철 수산화물이나 점토광물과 같은 단열 충전광물들에 의해 이루어짐을 재차 확인하였다.

퇴적물 내 핵종이동과 관련하여 가장 잘 알려진 자연 유사연구는 스코틀랜드 남부 Highlands에 있는 Loch Lomond에서 수행 된 것이다[68]. 이 퇴적물들은 점토 함량이 $80 \%$ 까지 매우 높다. Loch Lomond 퇴적물 코어 시료들의 분석으로부터 다양한 원소들에 대한 농도 구배를 구성하 였고, 이것들을 이용하여 유동 및 지연 과정들을 결정하였
다. 또한 영국 스코틀랜드의 Needle's Eye 연구부지에서 도 우라늄과 토륨의 동위원소비를 이용한 핵종 이동 및 지 연 과정 메커니즘에 대한 연구가 수행되었다[69]. 가봉의 Oklo 자연유사연구 부지에서도 핵종이동 및 지연에 관한 연구가 수행되었다[70]. 반응기 주변에서 수 십 센티미터 정도의 희토류 원소들과 우라늄의 이동이 발생하였고, 이 차상 광물들(점토 광물, 탄산염 단열충전물, 저어콘과 같 은 부성분광물)이 암반내에서 핵종지연에 책임이 있는 것 으로 관측되었다. 이러한 연구결과들은 확산 지배적인 점 토질 처분장 환경에 적용될 때 가장 유용하다.

체코의 Ruprechtov 우라늄 광 연구부지에서는 제3기 점토질 퇴적물에서 우라늄의 유동성을 조사하는 연구가 수행되었다[71]. 이 연구에서는 Ruprechtov 부지에서 우 라늄의 이동경로와 지질학적 진화(evolution)에 대한 새로 운 개념적 모델 개발되었다. 우라늄의 이동은 3 가지 다른 과정들, 즉 고령토를 통한 확산, 고령토를 가로지르는 단 층지역을 통한 이류, 고령토와 3 기층 경계에서의 대수층 을 통한 이류 이동 등에 의해 주로 결정되었다. 최근에는 캐나다 Cigar Lake 우라늠 광 주변에서 accelerator mass spectrometry (AMS) 라는 새로운 분석방법을 이용하여 ${ }^{36} \mathrm{Cl}$ 의 이동 특성에 대한 연구가 수행되기도 하였다[72]. 우라늄광, 암석, 점토와 단열충전광물에서의 ${ }^{36} \mathrm{Cl}$ 의 농도 는 Monte Carlo 모사에 의해 예측된 결과와 모두 일치하 였다. 더구나 단열과 인접한 암반체에서 측정된 ${ }^{36} \mathrm{Cl}$ 의 농 도가 예측된 값과 크게 다르지 않았다.

성능평가 모델들은 암석의 수착능에 대한 정량적인 표 현을 필요로 한다. 이것은 보통 고체상와 액체상 사이의 원 소의 분배 관점에서 표현되는 분배계수(distribution coefficient, $\mathrm{K}_{\mathrm{d}}$ )로 표현된다. 다양한 범위의 물-암석 쌍에 대해 실험적으로 결정한 엄청난 수의 $\mathrm{K}_{\mathrm{d}}$ 값들이 존재한다. 그러 나 불행하게도 $\mathrm{K}_{\mathrm{d}}$ 값의 사용은 처분장 환경에 대한 불적 절한 대표성으로 인해 지적 받고 있다. 한 예로, 처분장의 단열 암반에서 핵종의 수착을 지배하는 것은 분쇄된 신선 한 암반이 아니라 단열 코팅 또는 표면 변질된 광물들이라 는 것이다. 또 다른 문제점들은 실험에 사용된 물이 현장 에서 채취된 물을 대표하고, 암석과 평형에 있는가 하는 것 이다. 이러한 문제를 극복하기 위하여 현장에서 $\mathrm{K}_{\mathrm{d}}$ 를 측정 하기 위한 연구들이 자연유사연구의 일환으로 수행되었 다. 일반적으로 현장(in-situ) $\mathrm{K}_{d}$ 를 측정하는 방법에는 세 가지 기본적인 방법이 있다. 첫 번째로 암석-물 쌍의 핵종 농도로 부터 측정하는 방법으로 이 방법은 기본적으로 실 험실적 회분식 방법의 현장 적용이라고 하겠다[73]. 두번째 로 핵종 농도구배로 부터 측정하는 방법으로 만약 지하수 
유동 속도가 알려져 있다면 수착성 추적자와 비수착성 추 적자 사이의 피크 체류시간(peak transit time)의 비로부터 지연인자를 직접 도출할 수 있다[68]. 마지막으로 동위원 소비로 부터 현장 $\mathrm{K}_{\mathrm{d}}$ 값을 결정하는 방법으로 $\mathrm{K}_{\mathrm{d}}$ 값을 지 하수와 암석에서의 방사성 핵종들의 동위원소 비로 부터 $\mathrm{K}_{\mathrm{d}}$ 값을 결정한다[74]. 그러나 이러한 방법은 과도하게 단 순화된 가정들이 포함되어 있어 현실적이지 못한다는 비 판을 받았다[75].

\subsection{3 암반체 확산}

방사성폐기물 처분 관점에서 암반체 확산의 중요성은 단열 표면으로부터 암반체로 이동하는 방사성 핵종들과 접촉하는 암반 면적을 크게 확대시킴으로써 핵종 이동의 지연효과를 얻는다는 것이다[76]. 암반에서 상호연결된 공 극들의 깊이와 부피에 대한 연구로 항만 구조물로 해수 에 30 년 동안 잠겨있던 화강암을 조사하는 연구가 수행 되었으며, 화강암에서의 $\mathrm{Cl}^{-}, \mathrm{Br}^{-}, \mathrm{F}^{-}, \mathrm{SO}_{4}^{2-}$ 등의 용질 확산 구배가 결정되었고 $\mathrm{Cl}^{-}$와 $\mathrm{Br}^{-}$에 대한 겉보기 확산계수(apparent diffusion coefficient)와 공극률 등이 계산되었다 [77]. 또한 광맥과 인접한 암석에서 침투하는 지하수의 재 분배된 원소들의 확산깊이를 측정하는 연구가 수행 되었다 [78]. 고려된 원소들은 $\mathrm{U}, \mathrm{Th}, \mathrm{La}, \mathrm{Nd}, \mathrm{Br}, \mathrm{Sr}, \mathrm{Ba}$ 등이었으 며, 원소들의 재분배는 $32 \mathrm{~mm}$ 와 $65 \mathrm{~mm}$ 깊이 사이에서 발 생하였는데 이것을 암반체 확산 깊이로 간주하였다. 암반 체 확산에 대한 보다 자세한 자연유사연구들이 잘 특성화 된 단열들에 인접한 결정질 암반을 대상으로 수행되었다 [62, 79-81]. Alexander 등은 심하게 변질된 화강암 암반체 에 대해서는 서로 연결된 암반 기공들이 $500 \mathrm{~mm}$ 정도 확 장되지만, 물리적으로 덜 변질되거나 열수력학적 활동이 적은 화강암에서는 이러한 확장이 제한된다고 보고하였다 [80]. 또 Alexander 등은 연결된 기공 깊이에 대해 $50 \mathrm{~mm}$ 정도가 현실적이고, $10 \mathrm{~mm}$ 는 충분히 보수적이라고 제안 하였다[81]. Mazurek 등은 북부 스위스 결정질 기반암으로 부터 채취한 시료들에서 $40 \mathrm{~mm}$ 까지의 암반체 확산깊이 를 보고하였다[82].

암반체 확산은 Palmottu 자연유사연구의 일부로 수행 되기도 하였다[83]. 분석결과는 핵종들의 분포가 단열에 서 암반으로 지수적으로 감소함을 명백하게 보여주었고, 한 시료에서는 약 $80 \mathrm{~mm}$ 까지 확산된 것이 확인되기도 하 였다. 스페인의 El Berrocal 자연유사연구 지역의 화강암 을 이용한 암반 확산실험에서는 우라늄의 확산깊이는 균 열표면으로부터 수 센티미터 정도에 불과하고, 모든 암반 이 확산에 유용한 것이 아니라고 보고하였다[84]. 아울러
Palmottu 부지에서는 암반 단열에 의해 경계지어진 두 암 반 시료들을 이용하여 암반 확산에 대한 정보를 얻었고, 우라늄의 공간 분포 및 확산 경로에 대한 정보들도 도출 하였다[85]. 결정질암에서의 암반체 확산에 포함된 과정 들에 대한 포괄적인 조사가 수행되었는데, 스페인의 Berrocal 자연유사연구 부지, 스웨 덴의 Stripa 시험 광, 캐나 다의 Underground Research Laboratory (URL), 스위스의 Grimsel Test Site 등 다수의 지역에서 채취한 화강암 시료 들을 비교하였다[86]. 우라늄의 실제 유동 깊이는 부지에 따라 달랐는데, 천부 El Berrocal 화강암에서는 $35 \mathrm{~mm}$, 심 부 El Berrocal 화강암에서는 $80 \mathrm{~mm}$, Stripa 화강암에서는 $25 \mathrm{~mm}$, 변질된 URL 화강암에서 $50 \mathrm{~mm}$, 변질 안된 URL 화강암에서도 $50 \mathrm{~mm}$ 인 것으로 나타났다.

단열 코팅광물 또는 암반에 인접한 열수 변질된 암반 등에는 $\mathrm{Fe}(\mathrm{II})$ 가 존재한다. 결정질 단열 암반에는 암반체 내 흑운모와 감섬석과 같은 광물들에 다량의 $\mathrm{Fe}(\mathrm{II})$ 가 존 재하고, 산화 지하수는 단열로부터 인접한 모암에서 효과 적으로 완충될 수 있을 것이다. Alexander 등은 암반의 암 반체 확산에 의한 완충 능력이 핵종의 용해도와 유동에 중 요할 뿐만 아니라 단열에서 형성되는 콜로이드 형성의 문 제를 완화시킬 수도 있음을 지적하였다[80]. 따라서 암반 체 확산에 의해 연결된 미세 기공들을 통해 지하수에 접근 할 수 있는 $\mathrm{Fe}(\mathrm{II})$ 의 양을 계산하는 것이 이러한 문제를 해 결하는데 매우 중요한 정보를 제공할 것이다.

\subsection{4 물-암반 상호작용 및 지구화학}

자연유사연구 부지에서 암반과 물의 상호작용을 연 구하기 위한 많은 연구들이 수행되었다. 핀란드의 Outokumpu 부지에서는 심부 결정질 암반에서 암석과 소금물 과의 상호작용을 연구하기 위하여 다양한 동위원소적 기 술들을 $\mathrm{U} / \mathrm{Th}$ 계열 핵종들에 적용하였다[87]. 결정질 편암 의 균열 시스템에는 두가지 다른 염수가 존재하였고, 우라 늄의 농도는 상대적으로 낮은 ${ }^{234} \mathrm{U} /{ }^{238} \mathrm{U}$ 동위원소비(1.63.4 )를 가진 0.05 에서 $0.5 \mathrm{ppb}$ 수준이었다. 최근에는 핀 란드 Askola 화강암 지대에서 우라늄 광물화 지역의 시추 공에서 채취한 시료들의 특성화 자료를 바탕으로 지하수 로 포화된 산화지역이라는 가정하에 모델링 연구를 수행 하였는데, 유출되어 나온 우라늄이 주어진 지화학적 환경 에서 uranyl silicates로 침전될 것이라고 예측하였다[88].

일본의 Tono 우라늄 광에서 시추공 암반시료들을 분 석함으로써 자연 환경에서 우라늄 계열 핵종들의 거동을 조사하였다[89]. ${ }^{234} \mathrm{U} /{ }^{238} \mathrm{U},{ }^{230} \mathrm{Th} /{ }^{234} \mathrm{U},{ }^{226} \mathrm{Ra} /{ }^{230} \mathrm{Th}$ 등의 동 위원소비를 a-, $\gamma$-spectrometer를 이용하여 분석하였다. 
퇴적암에서 지난 100 만 년 이상 환원환경이 유지되었음 을 확인하였고, 단층과 단열을 따라 우라늄의 이동이 관 측되기는 하였으나 지난 백만 년 동안 우라늄이 암반체 를 통해 $1 \mathrm{~m}$ 보다 작은 거리를 이동한 것으로 평가되었 다. 이에 반해 라듐은 Tono 광에서 지난 수 천 년 동안 유 동하였음을 관측하였다. 이태리의 Pliocenic 점토 퇴적물 에서 우라늄과 토륨 동위원소 계열을 이용한 연구에서는 350,000 년 동안 열린 시스템이 유지되었고, 되튐(recoil) 생성물들이 공극수로의 확산에 의해 유동이 일어났음을 관측하였다[90].

Ivanovich 등은 영국의 Permo-Triassic 사암 부지에서 우라늄 계열 핵종들을 이용하여 물/암석 상호작용을 연구 하였다[91]. 지하수의 우라늄 농도는 0.3-13.6 ppb 정도였 으며, ${ }^{234} \mathrm{U} /{ }^{238} \mathrm{U}$ 동이원소비는 1.6 - 13.8 정도였다. 고체/ 액체 표면 교환과정의 연대와 $\mathrm{U}$ 와 Th의 지연인자들을 평 가하기 위해 1 차원 이류모델이 사용되었다. 연구 결과, 평 균 지하수의 지체 시간은 250-270 년 정도인 것으로 평가 되었고, $\mathrm{U}$ 와 $\mathrm{Th}$ 의 지연인자는 각각 $10^{3}$ 과 >105 수준으로 평가되었다. 또한 침전 속도 상수 값은 대수층에서 이러한 과정이 우라늄 보다는 토륨에 훨씬 더 중요하다는 것을 나 타내었다. 스페인의 Mina Fe 연구 부지에서도 물/암석 상 호작용 과정에 대한 연구가 수행되었다[36, 92]. 이 지역 의 지하수는 $\mathrm{Ca}_{-} \mathrm{SO}_{4}$ 형의 산성 산화 지하수에서 알카리 환 원 지하수로 진화함를 보여주었는데, 이는 단열충전광물 인 탄산염 광물들의 완충 능력에 기인한 것으로 보고하였 다[36]. 또한 Arcos 등은 Mina Fe 부지에서 발생하는 주요 지화학적 과정들을 통합하기 위하여 개념적인 광물학적 지화학적 모델을 개발하였는데, 반응용질 이동모델로부 터 얻은 결과들은 이전 결과들과 잘 일치함을 보였다[92].

\section{2 .5 콜로이드}

방사성폐기물 처분과 관련하여 콜로이드의 중요성은 많은 연구자들에 의해 인식되어 왔다. 콜로이드는 $1 \mu \mathrm{m}$ 에서 $1 \mathrm{~nm}$ 정도의 크기를 가지는 입자성 물질로 지하수에 분산되어 존재한다. 콜로이드의 특성과 핵종이동에 대한 콜로이드의 영향을 조사한 자연유사연구는 많이 있었지만 처분장 성능평가에 충분한 정보를 제공할 수 있는 연구는 많지 않다. 캐나다 Cigar Lake 자연유사연구의 일환으로 우라늄 광 내 또는 광으로 부터의 핵종이동에 미치는 콜로 이드의 영향을 평가하기 위한 연구가 수행되었다[44, 93]. Cigar Lake 부지의 물리화학적 조건들은 실제 처분장 환경 과 매우 유사하기 때문에 처분장에서 콜로이드의 거동을 예측하는데 매우 유용한 정보를 제공하였다. Cigar Lake의
심부 지하수에서 콜로이드 농도는 $8 \mathrm{mg} / \mathrm{L}$ 정도인 것으로 측정되었고, 핵종 농도의 $0.01 \%$ 보다 작은 양이 콜로이드 에 수착되는 것으로 계산되었다[44]. 따라서 콜로이드 농도 가 너무 낮기 때문에 콜로이드로의 핵종 수착이 가역적이 라면 콜로이드가 핵종 이동에 거의 영향을 미치지 않을 것 으로 추정되었다. 우라늄광 주변과 우라늄 광에 존재하는 입자들의 $\mathrm{U}, \mathrm{Th}$ 함량이 사암에 존재하는 양보다 매우 높 게 나타났는데 이것은 점토층이 입자들의 이동에 효과적 인 방벽이 될 수 있음을 나타낸다[93].

브라질의 Poços de Caldas 자연유사연구의 주요한 목 적 중 하나는 원소들의 이동과 관련한 콜로이드 이동의 중 요성을 정량화 하는 것이었다. Osamu Utsumi 우라늄광과 Morro do Ferro 토륨광 등 두개의 연구 부지는 각기 다른 암석-물 시스템을 가지고 있다. 이들 부지에서의 콜로이드 채취 방법과 실험 결과들은 Miekeley 등에 의해 자세히 제 시되었다[94]. Osamu Utsumi 우라늄광에서는 심부와 천 부 지하수에서의 콜로이드 특성에 확실한 차이를 보였다. 천부에서는 주로 점토 입자들로 구성된 $0.8 \mathrm{mg} / \mathrm{L}$ 정도의 콜로이드 농도가 측정되었고, 심부에서는 주로 비정질 철 옥시수산화물로 구성된 $0.05-0.5 \mathrm{mg} / \mathrm{L}$ 정도의 콜로이드 농도를 보였다. 콜로이드의 ${ }^{234} \mathrm{U} /{ }^{238} \mathrm{U}$ 동위원소비는 지하 수의 동윈원소비와 거의 유사하였는데 이는 지하수와 콜 로이드가 서로 평형상태에 있음을 나타낸다. 그러나 콜로 이드의 ${ }^{230} \mathrm{Th} /{ }^{234} \mathrm{U}$ 동위원소비는 지하수의 비보다 훨씬 크 게 측정되었는데 이것은 토륨이 콜로이드에 의해 우선적 으로 잡히거나 우라늄이 콜로이드로 부터 우선적으로 유 출되었음을 의미한다. 이러한 결과는 우라늄의 대부분이 용액에 존재하였고, 토륨의 $70 \%$ 이상은 콜로이드에 존재 한 비교분석 결과와 일치한다. Morro do Ferro 토륨광에서 는 지하수의 흐름 시스템에 따라 지하수 및 콜로이드 시료 를 채취할 수 있었는데 콜로이드의 조성은 Osamu Utsumi 우라늄광에서 채취한 콜로이드와 매우 유사하였다. 그러 나 콜로이드 농도는 0.1-3.1 mg/L로 Osamu Utsumi 우라 늠광보다 높았다. 동위원소 비는 Osamu Utsumi 우라늠광 과 유사한 결과를 보였다.

호주의 Alligator Rivers 자연유사연구 부지에서도 콜 로이드의 핵종이동에 대한 영향을 평가하기 위한 자연유 사연구가 수행되었다 $[95,96]$. 지하수에서 실제 콜로이드 개체수는 매우 낮은 것으로 $\left(10^{6}\right.$ colloids/L 이하) 나타났 다(Grimsel Test Site의 경우엔 $10^{11}$ colloids/L 정도 였다). 비록 Alligator Rivers 연구 부지에서 콜로이드에 의한 핵 종의 이동은 거의 무시할만 한 것으로 나타났지만, 지표 와 가까운 산화 환경에서 도출한 결과들이라 심부 환원환 
경의 처분장에 직접 이러한 연구결과를 적용하기에는 어 려움이 있다.

콜로이드에 대한 자연유사연구 결과들은 대부분 지하 수에서의 콜로이드의 농도가 낮아서 핵종이동에 큰 영향 을 미치지 않을 것으로 나타났지만, 콜로이드의 농도가 낮 다고 하더라도 이는 지하수에 유출되어 존재하는 핵종들 의 농도에 비하면 매우 큰 것이고, 콜로이드들이 매우 큰 비표면적으로 인해 핵종들의 수착능이 높다는 점을 고려 해야 한다. 또한 Cigar Lake로 부터 콜로이드에 대한 정보 들은 비록 콜로이드 농도는 매우 낮지만 콜로이드들이 매 우 안정적이고 우라늄들은 콜로이드에 비가역적으로 결 합하고 있음을 나타내었다[119]. 이것은 장기간에 걸쳐 이 류적인 콜로이드의 이동에 의해 핵종이동에 영향을 미치 기에 충분한 콜로이드 농도인 것으로 판단되었다. 이것은 처분안전성과 관련한 콜로이드의 중요성에 있어 콜로이 드의 안정성과 비가역성이 콜로이드의 농도보다 중요함 을 의미한다.

\subsection{6 미생물}

방사성폐기물 처분에서 미생물의 역할이나 중요성은 Baik 등이 잘 정리하였다[97]. 방사성폐기물 처분에 대한 미생물 활동의 영향은 1980년대 중후반부터 많은 국가들 의 방사성폐기물 처분연구 프로그램에 포함되어 수행되 어져 왔으나 자연유사연구부지에서의 미생물 관련 연구 는 매우 제한적으로 수행되었다. Pederson 등은 가봉의 Bangombé, 핀란드의 Palmottu, 스페인의 Maqarin 등의 자연유사연구 부지에서 미생물 관련 연구를 수행하였다 [98, 99]. Bangombé와 Palmottu 부지에서 조사된 미생 물의 개체수는 $10^{4}-10^{6} \mathrm{cells} / \mathrm{mL}$ 정도로 관측되었다. IRB (iron reducing bacteria)는 Palmottu 지하수에서 가장 많 은 미생물 개체로 확인되었으며 $1.3 \times 10^{5} \mathrm{cells} / \mathrm{mL}$ 까지 존 재하였다. IRB와 SRB (sulfate reducing bacteria) 개체수 는 우라늄 농도가 가장 낮은 곳에서 가장 많은 것으로 관측 되었다. Palmottu에서의 미생물의 총 개체수는 깊이에 따 라 감소하는 경향을 보여주었는데 이것은 스웨덴의 Äspö HRL (Hard Rock Laboratory)에서 관측된 결과와 일치하 였다. 혐기성 환원 미생물들의 개체수는 깊이에 따라 증 가하였다.

Bangombé 부지에서의 연구결과들은 IRB 및 SRB 등 혐기성 환원 미생물들이 유기물질을 산화시키고, $\mathrm{Fe}(\mathrm{III})$ 및 $\mathrm{SO}_{4}^{2-}$ 를 환원시켜 $\mathrm{Fe}(\mathrm{II})$ 와 $\mathrm{S}^{2-}$ 를 각각 생성함을 보여주 었다. 또 Bangombé 지하수에 대한 호기성 및 혐기성 미
생물 활동의 주요한 영향은 용존 산소 및 고체 $\mathrm{Fe}(\mathrm{III})$ 의 소 모와 $\mathrm{CO}_{2}$ 의 생성인 것으로 관측되었다. Palmottu 부지에 서 연구결과는 IRB, SRB가 많을 수록 낮은 산화환원전위 를 나타내었지만, 미생물 활동이 산화환원 전위를 감소시 킨다는 결론을 내리기엔 자료가 부족하였다. 특히, 배양 증가된 IRB에서 우라늄의 환원이 관측되었다. 따라서 미 생물들이 Palmottu 지하수 시스템의 환원상태 유지에 기 여하고, $\mathrm{U}(\mathrm{VI})$ 의 $\mathrm{U}(\mathrm{IV})$ 로의 환원에 직접적으로 관여할 것 이라고 판단하였다.

Maqarin 부지에서 유출되는 지하수는 초알칼린이며 지화학적으로 포틀랜드 시멘트 공극수와 유사한다. 따라 서 이 부지는 중·저준위 방사성폐기물처분장과 같이 높 은 $\mathrm{pH}$ 환경을 가지는 처분장에 대한 훌륭한 자연유사 부 지이다. 연구의 주요 관심은 Maqarin 부지와 같이 극한의 $\mathrm{pH}$ 환경에서 미생물이 생존하고 활동할 수 있는가 하는 것이었다. 측정 결과, 모든 Maqarin 지하수에서 미생물들 이 관측되었다. 그러나 이것이 미생물들이 중성의 지하수 로 부터 이동하여 들어온 것이 아니고 현장에서 생존하여 성장한 것이라는 결론을 내리기에는 자료가 부족하였다. 현재 미생물의 역할과 핵종이동 영향에 대한 많은 실험실 적 연구들이 수행되고 있지만 자연유사연구는 매우 제한 적이다. 따라서 향후로는 더 많은 자연유사연구가 수행될 필요가 있다.

\section{3. 국내 자연유사연구 동향 분석}

국내에서는 1996-1999년 동안 한국원자력연구소에서 OECD/NEA 주관의 호주 Alligator Rivers 지역의 Koonggarra 우라늄광 국제공동연구인 ASARR Project에 부분 참 여하였다[100]. 아울러 국내 자연유사연구 대상지역 현황 을 분석하고 예비평가 연구를 수행한 바가 있다[12]. 그 외 에도 지하 암반을 통한 핵종이동 현상과 관련하여 암반을 통한 핵종확산에 대한 자연유사연구의 적용성을 검토한 연구가 수행된 바가 있으며[102], 역사시대 고분을 이용한 중 · 저준위 방사성페기물 천층처분 덮개성능에 대한 자연 유사연구 등이 수행 된 바가 있다[102]. 그러나 국내에서는 아직 방사성폐기물 처분관점에서의 본격적인 자연유사연 구가 거의 수행되지 않고 있는 실정이다.

여기에서는 그동안 국내에서 수행되어 온 방사성폐기 물 처분관점 뿐만 아니라 우라늄 광산이나, 암석 및 지하 수에서의 핵종거동과 관련된 소규모의 자연유사적 연구결 과를 우라늄 광상 연구, 암반을 이용한 연구, 지하수를 이 
용한 연구, 고고학적 유물을 이용한 연구 등으로 구분하여 간략하게 정리하였다.

\section{1 우라늄 광상 연구}

수 십 년 전부터 국내 우라늄광의 분포와 개발의 타 당성을 조사하기 위한 연구들이 꾸준하게 수행되어져 왔 으며, 때로는 대규모의 탐사연구도 수행 된 바가 있다[12]. 국내에서 우라늄 부존 가능성이 가장 높은 옥천대의 중 부에 분포하는 함우라늄 탄질 흑색슬레이트의 퇴적환경 및 지구화학적 측면에서 다양한 특성들을 규명하는 연구 가 수행되었다 $[103,104]$. 옥천대 우라늄광의 경우, $\mathrm{U}_{3} \mathrm{O}_{8}$ 의 우라늄 품위는 0.02-0.5\% 정도이고, 주요 우라늄광물은 ferro-uranophane, chlopinite, uraninite 등이고, 그 밖에 도 coffinite, haiweeite, magnioursilite 등의 존재가 보고 되었다[104]. 옥천대 우라늄광에서는 우라늄 광상의 미량 원소 분석, 우라늄 광상의 안정동위원소 분석, 우라늄 광상 의 성인 등에 대한 지구화학적 연구들이 주로 많이 수행되 었다. 이러한 연구들을 통해 옥천대 우라늄 광화는 유기물 과 유화광물의 침전이 수반되는 퇴적환경에서 이루어 졌 음이 입증된 바 있다[104].

옥천변성대의 대표적인 우라늄 광산대인 괴산군 덕평 리 일대의 흑색점판암과 이에 협재하는 함우라늄 탄질점 판암을 상호 구분하여 이들에 대한 지구화학적 연구를 수 행함으로써 우라늄 광상의 생성환경에 대한 연구가 수행 된 바가 있다[105]. 덕평리 일대 우라늄 광화작용은 해저열 수활동의 영향을 받고 산소가 결핍된 유기물이 풍부한 퇴 적분지에서 형성된 것으로 해석된다[105]. 최근에는 옥천 변성대 남서부에 위치하는 전라북도 진안군 신보광산과 그 동부지역에서 지하수 및 지표수에 관한 수리화학 및 동 위원소적 연구를 통해 고품위 우라늄 지화학 이상대가 존 재함이 보고된 바가 있다[106, 107]. 이러한 국내 우라늄광 에 대한 장기간에 걸치 다양한 연구가 수행되었음에도 불 구하고, 방사성페기물 처분관점에서의 자연유사연구가 심 도있게 수행되지 못한 것은 참으로 안타까운 일이다.

\section{2 암반을 이용한 연구}

국내에 분포하는 암종 가운데서 대보화강암 분포지역 의 지하수에서 우라늄의 평균 함량이 가장 높으며, 100 $\mathrm{ppb}$ 이상의 우라늄이 포함된 지하수 공의 개수도 가장 많
은 것으로 밝혀졌다[108]. 대보화강암에 존재하는 우라늄 광물은 주로 저어콘, 모나자이트, 제노타임과 같은 부성분 광물 내에 함유되는데 대부분 미량성분이나 포획물로 들 어 있으며, 모암 내의 우라늄 함량과 지하수중 우라늄의 함 량이 서로 큰 관련성이 없는 것으로 나타나 우라늠 광물이 용해될 수 있는 수리화학적 환경 외에도 우라늄 광물의 산 출 특성과 존재형태도 중요한 요소임이 확인되었다[108].

대전에 위치한 한국원자력연구원(KAERI) 연구지역의 화강암을 대상으로 암석에서의 우라늄 분포특성을 EPMA (Electron Probe Micro Analyzer)를 이용한 후방산란 전 자이미지(backscattering-electron imge) 및 원소매핑(element mapping) 기술로 분석하였다. 연구결과, 우라늠을 포함하는 주요 방사성 핵종들이 화강암의 주 구성광물중 하나인 흑운모로부터 용출되어 나온 철이온이 형성한 철 산화 이차광물들과 결합하여 존재하고 있음을 확인하였으 며, 아울러 암반을 따라 이동하는 방사성 핵종들의 지연특 성에 대한 연구를 수행한 바 있다[109-111]. 또한 화강암과 화강암 구성광물과의 상호작용에 의한 우라늄의 수착 메 커니즘에 대한 연구들이 실험실적 연구를 통해 수행되기 도 하였다[112]. 그러나 암반에서의 핵종 이동 및 지연, 지 하수와의 상호작용 등에 대한 자연유사연구는 수행된 바 가 없다.

\section{3 지하수를 이용한 연구}

국내 지하수의 자연방사성물질 함량에 대한 전국적인 규모의 조사는 1998년 6월 국내 일부 지하수의 우라늄 함 량이 특정 국가(미국 $\mathrm{EPA})$ 의 기준치(30 ppb)를 상회하였 다고 보도된 이후인 1999년부터 꾸준히 이루어졌다[113, 114]. 1999년부터 2002년까지 그리고 2006년부터 2007년 까지 지하수의 자연방사성물질 함량 실태조사가 국립환경 과학원과 지질자원연구소에 의해 이루어졌다[113]. 아울 러 복운모 화강암 분포지역의 일부 지하수에서 $100 \mathrm{ppb}$ 가 넘는 고농도의 우라늄이 검출되고 있으며, 지하수의 심도 와 대수층의 발달 정도에 따라 우라늄의 함량 범위는 다양 하게 나타났다[114], 따라서 운모류를 대상으로 방사성 광 물의 존재를 밝히는 것이 중요할 것으로 여겨진다. 그리고 국내에서는 아직 지하수에 존재하는 우라늄 계열의 자연 방사성핵종들 $(\mathrm{U}, \mathrm{Th}, \mathrm{Ra}$ 등)의 동위원소비 분석 등을 통한 지구화학적 자연유사연구는 수행 된 바가 없으므로 이러한 연구의 수행이 필요하다. 


\section{4 고고학적 유물을 이용한 연구}

방사성폐기물 처분과 관련하여 국내에서 유일하게 수 행 된 고고학적 유물을 이용한 자연유사연구는 중 - 저준위 방사성페기물 천층처분시설의 처분덮개 설계 및 성능 평 가를 위한 국내 삼국시대 고분을 이용한 연구이다[102]. 국 내 고분에 대한 보토의 시료채취와 시료에 대한 수리전도 도 측정 및 분석을 수행하였다. 고분 시료의 수리전도도는 점토와 모래 혼합(70:30) 토양과 실트와 모래 혼합(70:30) 토양의 중간 정도의 특성을 보여주었다. 고분에 대한 자연 유사연구에서 발굴 조사보고서 상에 제시된 봉토의 유사 판축기법이나 모세관 방벽현상과 배수로를 이용한 봉분 내 습도조절 방법 등은 천층처분 시설설계에 활용될 수 있 을 것으로 제안되었다. 그러나 본 연구는 처분관점에서 진 행된 고분연구 문헌의 부족과 봉토의 층상 구조를 파악할 수 있는 고분의 수적 부족 등의 이유로 수행 된 연구내용과 결과가 매우 제한적이었다. 따라서 고분을 이용한 자연유 사연구 수행 시엔 고분 발굴 시에 현장에서 관련 시료와 자 료를 확보하는 것이 필요하며, 국내 고고학계와의 정보 교 환이 필요하다고 제안하였다.

\section{4. 자연유사연구의 결과의 활용}

자연유사연구로 수행되었던 또 수행되고 있는 지질학 적, 고고학적 시스템들은 필수불가결하게 매우 복잡하다. 따라서 특정한 지화학적 과정 또는 기작을 모델화하기 위 해 필요한 물리화학적 경계조건들을 적절하게 정량화하는 것은 매우 어렵고, 어떤 때는 불가능하다. 이러한 자연유 사연구 결과들을 처분장 안전성평가에 정량적으로 적용하 는 것은 매우 어려운 일이지만, 자연유사연구가 안전성평 가보다 포괄적인 safety case에서 중요한 역할을 한다는 것 은 명백한 사실이다. 일반적으로 방사성폐기물 처분장의 성능평가 또는 안전성평가에 자연유사연구결과를 활용할 수 있는 방법는 크게 직접적인 활용 방법과 간접적인 활용 방법으로 나눌 수 있다[1].

\section{1 직접적인 활용 방법}

몇몇 국가들의 안전성평가들에서는 자연유사연구 자 료들이 직접적으로 활용되기도 하였고, 또 부분적으로 활 용되기도 하였다[8]. 스위스 Nagra에서 수행한 KRISTALLIN-I 안전성평가에서는 안전성평가 신뢰성 구축, 안전
성평가 방법론과 모델들의 개발, 공학적방벽들, 암반체 확산 등과 같은 분야들에 대한 입력자료로 자연유사연구 자료들이 직접 활용되기도 하였다[115]. 그리고 스웨덴의 SKB-91 안전성평가[116]와 일본의 PNC-H3[117] 등에서는 자연유사연구 자료들이 부분적으로 활용되었지만, Yucca Mountain 안전성평가[118]에서는 거의 활용되지 않았다. 자연유사연구 자료를 직접적으로 활용하는 방법은 크게 다음과 같이 세가지로 분류할 수 있다[1].

· 정량적인(hard) 방법: 안전성평가에 수치적 입력자 료로 활용

· 정성적인(soft) 방법: 설명에 의한 개념적 모델들의 신뢰성 구축

· 설명적인 방법: 일반대중과의 관계 또는 인지적인 것

자연유사연구 자료들의 정량적인 활용은 일반적으로 처분용기 물질의 부식률, 벤토나이트 뒷채움재/완충재의 안정성, 결정질 암반체로의 핵종 확산깊이의 범위 측정, 용해도한계를 제공하는데 사용되는 지화학코드와 열역학 적 데이터베이스의 검토 등의 분야에 한정되어야 한다는 것이 전문가들의 견해이다[1, 8]. 그러나 다양한 분석기술 과 해석기법들이 개발됨에 자연유사연구 자료들의 직접 적인 활용분야도 점차 확대되어 가고 있는 추세이다. 그러 나 자연유사물의 본질적인 특성에 의해 직접적인 활용은 여전히 한계성을 가지고 있다. Table 1 에 자연유사연구의 직접적인 활용의 예들을 정리하여 나타내었다. 반면에 자 연유사연구 자료의 정성적인 활용은 지금까지 자연유사연 구 결과들이 가장 편리하게 활용된 분야라 하겠으며 많은 예들이 보고서나 논문 등을 통해 제시되었으며, 그 주요한 예는 다음과 같다[1].

· 추적자원소의 이동과 지연에 관련된 redox front의 이동의 파급효과

- 지하수의 흐름에 대한 수력학적 방벽으로써의 점토 의 기능

· 점토에 의한 방사성핵종 지연 특성

· 콜로이드 물질에 의한 핵종이동 영향을 지지할 수 있는 증빙자료

\section{2 간접적인 활용 방법}

자연유사연구 자료들은 처분 안전성평가에 간접적 


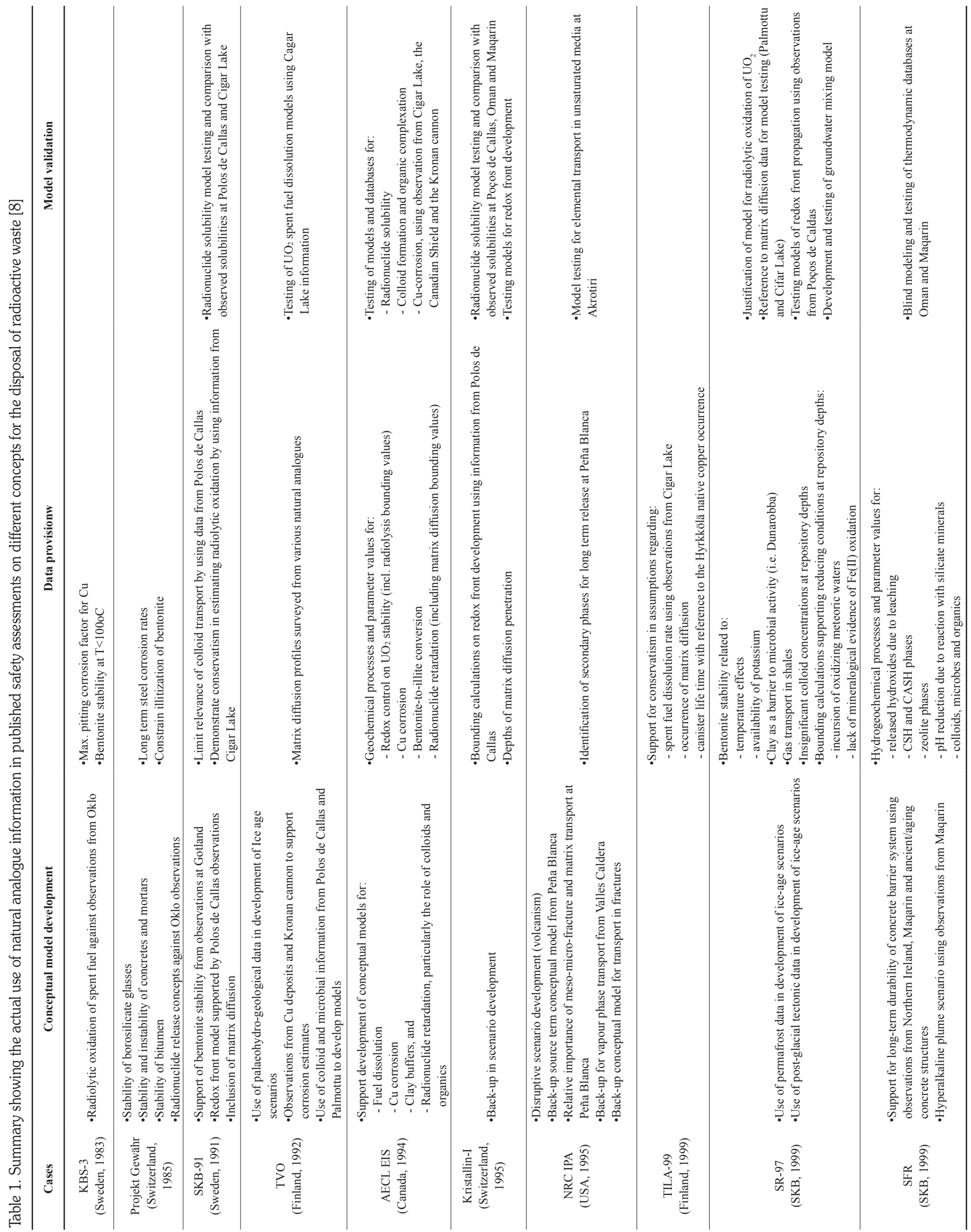


으로도 활용될 수 있다. 그 대표적인 예가 수많은 중요한 FEPs (Features, events, and processes)들이 확인되고 기 술되어야 하는 안전성평가를 위한 체계적인 시나리오 개 발이라 하겠다. FEPs의 예로는 침전/용해, 수착/공침, 방 사분해, 폐기물 포장물의 물리적 특성, 벤토나이트 뒷채움 재와 시멘트/콘크리트의 물리적 특성, 가스생성 및 이동, 미생물 활동 등 매우 다양하다. 실험실적 자료 및 현장자 료들과 함께 자연유사 자료들의 역할은 시나리오 개발에 서 각기 다른 FEPs들을 지원하거나 또는 이들을 시나리오 에 포함하는 것이다. 최근 시나리오 개발에서 자연유사 자 료들의 활용성이 증가하는 것은 매우 고무적이라 하겠다.

\section{3 자연유사연구 활용성의 장애요인 및 증진 방안}

비록 몇몇 안전성평가에서 자연유사 자료들을 어느 정 도 통합적으로 활용하여 왔다고는 하지만 이들 자료들의 활용은 아직 폭넓게 인식되고 있지 못한 실정이다. 자연유 사 자료들의 활용성에 장애가 되는 것으로 인식되고 있는 문제점들은 안전성평가에 요구되는 적합한 자연유사 자료 들의 취득과 전달의 부적절함, 단순한 안전성평가 모델들 의 입력자료로 매우 복잡한 자연유사 자료들을 이용하는 데서 오는 어려움, 지구과학적 연구자들 그룹과 안전성평 가자 그룹 사이의 대화와 소통의 부재 등이다 $[1,2]$. 특히, 지구과학적 연구자 그룹 및 안전성평가자 그룹 간의 소통 을 위해서는 그룹 사이에 조정 역할을 하는 중간자 그룹 이 필요하다고 하겠다. 이러한 두 그룹 간의 대화와 소통 의 증진이 처분장 안전성평가에서 자연유사연구의 중요성 을 인식하고, 활용성을 증진시키는데 중요한 역할을 할 것 으로 판단된다.

\section{5. 요약 및 결론}

본 연구에서는 해외의 자연유사연구 동향을 조사하여, 처분장 재료물질들과 핵종이동 및 지연과 관련된 자연유 사연구 결과들을 연구주제별로 정리하고, 주요 연구결과 와 문제점, 결과의 활용성 등에 초점을 두고 분석하였다. 처분장 재료물질들에 대해 고려된 주요한 연구주제들 및 분석결과들을 요약하면 다음과 같다.

· 붕규산염 유리: 심지층처분환경의 지하수에서 유리
고화체의 수명은 $10^{7}$ 에서 $10^{8}$ 년 수준으로 예상되지 만 처분환경에 타당한 환경 및 물질들을 이용한 연구 결과는 많지 않다.

- 사용후핵연료: 타당한 처분장의 지질학적 조건들에 서 우라니나이트의 용해율은 매우 느리고, 비록 높 은 방사능 준위의 장기적인 영향에 대해서는 여전히 불확실성이 높지만 사용후핵연료는 상당히 긴 시간 동안 지속성을 보일 것이라고 보고하고 있다. 사용 후핵연료의 용출에 의한 우라늄광물 형성 및 지하수 와 반응에 의한 이차광물의 형성 등에 대한 연구가 최근에 많이 수행되었다.

- 금속: 구리의 피팅인자 및 부식률은 처분 안전성평 가의 입력인자로 활용될 수 있으며 고고학적 유물을 이용한 유사연구 결과들은 측정된 피팅인자가 실제 안전성평가에 사용된 값보다 보수적임을 보였고, 부 식률도 낮아서 $10 \mathrm{~cm}$ 정도 두께의 구리 처분용기의 경우엔 수 십만 년에서 수 백만 년 정도의 수명을 가 질 것으로 예상되었다. 그러나 타당한 처분장 조건 에 부합하는 고고학적 유물들에 대한 자료는 부족한 상태이다. 철에 대한 고고학적 유사물들은 철 부식 이 250,000 300,000 년 정도 걸리는 것으로 나타내 었지만, 철 부식에 이한 이차생성물의 영향에 대해서 는 추가적인 연구가 필요하다.

· 벤토나이트: 벤토나이트의 변질과 수력학적 방벽, 타 물질과의 상호작용, 콜로이드 여과 기능 등에 대 한 자연유사연구가 수행되었지만, 타당한 처분장 조 건에서 수행 된 자연유사연구 결과는 매우 제한적이 다. 따라서 보다 다양한 조건(특히, 국내 지질환경) 의 벤토나이트 광산을 대상으로 한 자연유사 연구 수 행이 필요하며, 암반과의 경계에서 발생하는 현상들 에 대한 자연유사연구가 추가로 필요하다.

· 시멘트와 콘크리트: 자연유사 연구결과들은 수 천 년 이상 동안 시멘트 화합물이 안정적일 것임을 보 여주었지만, 콘크리트와 시멘트에 대한 자연유사연 구는 아직 많지 않다. 암반 등 다른 물질과의 상호작 용, 핵종 수착특성에 미치는 영향, 콜로이드 생성 및 여과 특성, 가스와 물 투과성, $\mathrm{CSH}$ 화합물의 결합 특 성 등에 대한 추가적인 연구가 필요하다.

또한 핵종이동 및 지연과 관련된 자연유사연구들에 대 해 고려된 주요 연구주제들의 분석결과들을 요약하면 다 음과 같다. 
- 용해도 및 화학종: 주로 지화학코드 및 열역학 데이 터베이스를 이용한 모델 검증 목적으로 다양한 연 구가 수행되었으나, 이 분야는 좀 더 엄격한 블라인 드 모델링 시험에 초점을 둔 연구들이 수행되어야 할 필요가 있다. 아울러 현장 화학종 규명기술의 개 발 및 적용을 위한 연구들과 함께 데이터베이스와 지화학코드 사이의 간격을 좁히기 위한 노력이 더 필요하다.

· 수착 및 지연: 실제 현장 조건을 반영한 핵종 수착 분배계수를 결정하기 위한 매우 다양하고 많은 연구 들이 수행 되었으나, 핵종 수착분배계수의 고유한 불 확실성으로 인해 실제 처분안전성 평가에 직접 활용 될 수 있는 자료들은 많지 않다. 열역학적 수착모델 을 이용한 수착거동을 해석하기 위한 연구들이 수행 되기도 하였으나 좀 더 체계적인 수착모델의 정립, 데이터베이스의 구축 등이 필요하며, 이 분야는 향 후 자연유사연구 결과의 활용성이 매우 높은 분야 로 고려되고 있다.

- 암반체 확산: 처분안전성 평가에 직접적으로 활용될 수 있는 암반 확산깊이와 확산계수 등을 결정하기 위 한 다양한 연구들이 수행되었다. 그러나 핵종의 용 해도와 단열 이동에 대한 암반체 확산의 영향, 단열 에서 형성되는 콜로이드 형성의 문제 등에 대한 추가 적인 연구 등이 필요하다.

- 물-암반 상호작용 및 지구화학: 최근에 많은 관심을 가지고 수행 되고 있는 연구 분야로 지하매질을 통한 핵종이동의 복잡한 상호작용을 이해하기 위해 다양 한 자연유사연구들이 수행되었으며, 지구화학적 과 정들을 핵종이동 모델에 통합하기 위한 반응용질 이 동모델 등의 적용 등이 주목받고 있는 분야이다.

- 콜로이드: 콜로이드에 대한 자연유사연구 결과들은 대부분 지하수에 존재하는(특히, 심부 지하수에 존 재하는) 콜로이드의 농도가 낮아서 핵종이동에 큰 영향을 미치지 않을 것으로 나타났지만, 핵종들이 콜 로이드에 비가역적으로 결합하고 있다는 연구 보고 가 있어 좀 더 엄밀한 연구의 수행이 필요한 분야 이다. 또한 타당한 처분장 조건에서 콜로이드 이동 및 콜로이드의 핵종이동 영향 등에 대한 연구가 필 요하다.

- 미생물: 현재 미생물의 역할과 핵종이동 영향에 대 한 많은 실험실적 연구들이 수행되고 있지만 자연유 사연구의 수행은 매우 저조하다. 최근에 미생물이
다양한 처분환경에 존재할 수 있음과 여러 가지 메커 니즘으로 핵종 거동에 영향을 미친다는 연구결과는 보고되었지만, 연구결과의 일관성 및 재현성이 부족 하고 불확실성이 크다. 따라서 향후로는 더 많은 자 연유사연구가 수행될 필요가 있다.

비록 많지는 않지만 국내의 자연유사연구 결과들을 우 라늄 광상 연구, 암반을 이용한 연구, 지하수를 이용한 연 구, 고고학적 유물을 이용한 연구 등으로 분류하고 조사 분석하였다. 국내에서 수행된 자연유사연구 주요 결과들 을 요약하면 다음과 같다.

- 우라늄광을 이용한 연구: 국내에서는 우라늄광을 개 발할 목적으로 장기간에 걸쳐 다양한 조사연구가 수 행되었음에도 불구하고, 방사성페기물 처분관점에 서의 자연유사연구가 수행 되지는 못하였다. 그러나 타당성 분석 연구를 통해 괴산군 덕평리 지역을 우라 늄광 자연유사연구부지로 제시한 바가 있다.

· 암반을 이용한 연구: 국내의 화강암반 지역을 대상 으로 우라늄 광물 특성 및 산출형태, 성인 등에 대한 연구들이 수행되었고, 대전에 위치한 한국원자력연 구원(KAERI) 연구지역의 화강암을 대상으로 암석에 서 우라늄 분포특성 및 광물과의 상호작용 등에 대한 연구들이 주로 수행되었다. 향후로도 지속적인 연구 수행이 필요한 분야이다.

- 지하수를 이용한 연구: 국내에서는 지하수 오염문제 등으로 지하수의 우라늄을 중심으로 한 조사연구가 수행되었지만, 주로 우라늄 존재양의 비교 및 지구 화학적 분석 위주로 수행되어 방사성폐기물 처분에 적용되기에는 어려움이 있다. 따라서 지하수에 존재 하는 우라늄 계열의 자연 방사성핵종들 $(\mathrm{U}, \mathrm{Th}, \mathrm{Ra}$ 등)의 동위원소비 분석이나 암반과의 상호작용에 의 한 우라늄 분포 특성 및 상관관계 해석 등 다양한 지 구화학적 자연유사연구의 수행이 필요하다.

· 고고학적 유물을 이용한 연구: 중 - 저준위 방사성페 기물 천층처분시설의 처분덮개 설계 및 성능 평가를 위해 삼국시대 고분을 이용한 유사연구가 수행되었 지만, 제시된 연구결과가 매우 제한적이었다. 그러 나 고분 발굴 시에 현장에서 관련 시료와 자료를 확 보하는 것이 필요하며, 국내 고고학계와의 정보 교 환이 필요하다고 제안하였다.

아울러 본 연구에서는 자연유사연구 결과의 안전성평 
가로의 활용 방법들을 정리하고, 활용성을 증진하기 위한 방법론을 검토하였다. 해외에서는 방사성페기물 처분시스 템의 성능 평가 및 처분 안전성평가를 위한 보조적인 도구 로 여러 부지들에서 다양한 분야에 걸친 많은 자연유사연 구 자료와 정보들을 축적하여 왔지만, 국내에서는 아직 방 사성폐기물 처분관점에서의 본격적인 자연유사 연구가 수 행되지 않고 있는 실정이다.

방사성폐기물 처분장 안전성평가의 신뢰성을 증진하 고 검증하기 위해서는 자연유사연구의 수행은 필수적이므 로 국내에서도 방사성폐기물 처분 관점에서의 자연유사연 구의 수행이 다양한 분야에서 본격적으로 수행되어야 할 필요가 있다. 따라서 본 연구의 결과는 향후 국내에서 자 연유사연구의 수행계획 수립 및 활용방안 개발에 유용한 정보를 제공할 수 있을 있을 것이다. 또한 매우 다양한 자 연유사연구 결과들을 safety case 개발에 활용하기 위해서 는 자연유사 정보자료의 구축과 함께 이를 안전성평가를 포함하는 safety case 개발에 활용할 수 있는 활용방법론이 개발되어야 할 필요가 있다.

\section{감사의 글}

본 논문은 원자력안전위원회에서 시행하는 원자력안 전연구개발사업의 일환으로 한국원자력안전기술원의 지 원을 받아 수행되었습니다.

\section{REFERENCES}

[1] J.A.T. Smellie, F. Karlsson and W.R. Alexander, "Natural analogue studies: present status and performance assessment implications", J. Contam. Hydrol., 26, pp. 3-17 (1997).

[2] W. Miller, R. Alexander, N. Chapman, I. McKinley and J. Smellie, Geological Disposal of Wastes and Natural Analogues - Lessons from Nature and Archaeology, Waste Management Series, Volume 2, Pergamon Press, Amsterdam (2000).

[3] IAEA, Natural analogues in performance assessments for the disposal of long lived radioactive wastes, International Atomic Energy Agency (IAEA) Technical Reports, Series No. 304 (1989).

[4] T. Papp, "The role of natural analogues in safety assessment and acceptability", in: Natural Analogues in Radioactive Waste Disposal, B. Côme and N.A. Chapman, eds, pp. 12-22, Graham \& Trotman, London (1987).

[5] N.A. Chapman, I.G. McKinely and J.A.T. Smellie, The Potential of Natural Analogues in Assessing Systems for Deep Disposal of High Level Radioactive Waste, Swedish Nuclear Fuel and Waste Management Company (SKB) Technical Report, KBSTR-84-16 (1984).

[6] W. Miller, The Value of Natural Analogues, Commission of the European Communities (CEC) Nuclear Science and Technology Report, EUR 16761 (1996).

[7] NEA, Post-closure safety case for geological repositories - Nature and purpose, Nuclear Energy Agency/Organization for Economic Co-operation and Development (NEA/OECD), Vienna (2004).

[8] IAEA, Use of natural analogues to support radionuclide transport models for deep geological repositories for long lived radioactive wastes, International Atomic Energy Agency (IAEA) Report, IAEA-TECDOC-1109 (1999).

[9] Natural Analogue Working Group, http://www.natural-analogues.com/

[10] B. Miller, P. Hooker, J. Smellie, J. Dalton, P. Degnan, L. Knight, U. Noseck, L. Ahonen, A. Laciok, L. Trotignon, L. Wouters, P. Hernan and A. Vela, Network to review natural analogue studies and their application to repository safety assessment and public communication (NAnet), Commission of the European Communities (CEC) Synthesis Report, EUR 21919 (2006).

[11] W. Miller, R. Alexander, N. Chapman, I. McKinley and J. Smelle, Natural Analogue Studies in the Geological Disposal of Radioactive Wastes, Swiss National Cooperative for Radioactive Waste Management (Nagra) Technical Report, NTB 93-03 (1994).

[12] C.S. Kim, D.S. Bae, K.S. Kim, Y.K. Koh and B.Y. Park, A Preliminary Feasibility Study of Natural Analogue in Korea, Korea Atomic Energy Research Institute (KAERI) Technical Report, KAERI/TR$1527 / 2000$ (2000).

[13] W. Lutze, G. Malow, R.C. Ewing, M.J. Jercinovic 
and K. Keil, "Alteration of basalt glasses: implications for modelling the long-term stability of nuclear glasses", Nature, 314, pp. 252-255 (1985).

[14] M.C. Magonthier, J.C. Petit and J.C. Dran, "Rhyolitic glasses as natural analogues of nuclear glasses: behaviour of an Icelandic glass upon aqueous corrosion", Appl. Geochem., Supplementary Issue 1, pp. 83-94 (1992).

[15] J. Bruno, I. Casa, E. Cera and L. Duro, "Development and application of a model for the long-term alteration of $\mathrm{UO}_{2}$ spent fuel. Test of equilibrium and kinetic mass transfer models in the Cigar Lake ore deposit", J. Contam. Hydrol., 26, pp. 19-26 (1997).

[16] R.J. Finch and R.C. Ewing, "Alteration of natural $\mathrm{UO}_{2}$ under oxidizing conditions from Shinkolobwe, Katanga, Zaire: A natural analogue for the corrosion of spent fuel", Radiochim. Acta, 52/53, pp. 395-401 (1991).

[17] J. Janeczek and R.C. Ewing, "Dissolution and alteration of uraninite under reducing conditions", J. Nucl. Mater., 190, pp. 157-173 (1992).

[18] K. Horie and H. Hidaka, "Redistribution of U, Pb and REE in association with alteration of uranium minerals from the Koongarra deposit, Northern Territory, Australia", Radiochim. Acta, 92, pp. 805-808 (2004).

[19] D.G. Brookins, "Radionuclide behaviour at the Oklo nuclear reactor, Gabon", Waste Management, 10, pp. 285-296 (1990).

[20] K.A. Jensen, C.S. Palenik and R.C. Ewing, "U6+ phases in the weathering zone of the Bangomber U-deposit: observed and predicted mineralogy", Radiochim. Acta, 90, pp. 761-769 (2002).

[21] L. Pérez del Villar, J. Bruno, R, Campose, P. Gómez, J.S. Cózar, A. Garralón, B. Buil, D. Arcos, G. Carretero, J.R. Sánchez-Porro and P. Hernán, "The uranium ore from Mina Fe (salamanca, Spain) as a natural analogue of processes in a spent fuel repository", Chem. Geol., 190, pp. 395-415 (2002).

[22] T. Iwatsuki, R. Arthur, K. Ota and R. Metcalfe, "Solubility constraints on uranium concentrations in groundwaters of Tono uranium deposit, Japan", Radiochim. Acta, 92, pp. 789-796 (2004).

[23] M.J. Apted, "Natural analogues for predicting the reliability of the engineered barrier system for high-level waste", J. Geochem. Explor., 46, pp. 35-62 (1992).

[24] R.F. Tylecote, "The effect of soil conditions on the long-term corrosion of buried tin-bronzes and copper", J. Archaeol. Sci., 6, pp. 345-368 (1979).

[25] A. Bresle, J. Saers and B. Arrhenius, Studies in pitting corrosion on archeaological bronzes, Swedish Nuclear Fuel and Waste Management Company (SKB) Technical Report, SKB TR 83-05 (1983).

[26] R.O. Hallberg, P. Ostlund and T. Wadsten, "A 17th century bronze cannon as analogue for radioactive waste disposal", in: Natural Analogues in Radioactive Waste Disposal, B. Côme and N.A. Chapman, eds, pp. 135-139, Graham \& Trotman, London (1987).

[27] N.R. Smart and R. Adams, Natural analogues for expansion due to the anaerobic corrosion of ferrous materials. Swedish Nuclear Fuel and Waste Management Company (SKB) Technical Report, SKB TR-06-44 (2006).

[28] A.B. Johnson and B. Francis, Durability of metals from archaeological objects, metal meteorites and native metals, Battelle Pacific Northwest Laboratory Report, PNL-3198 (1980).

[29] J. Dresselaers, F. Casteels and H. Tas, "Corrosion of construction materials in clay environments", Scientific Basis for Nuclear Waste Management, IV, pp. 311-319 (1983).

[30] B. Hofmann, Geochemistry of natural redox fronts a review, Swiss National Cooperative for Radioactive Waste Management Techchical Report, NTB 95-07 (1997).

[31] H.E. Roberson and R.W. Lahann, "Smectite to illite conversion rates: effects of solution chemistry", Clays Clay Miner., 29, pp. 129-135 (1981).

[32] R. Pusch and O. Karnland, Geological evidence of smectite longevity. The Sardinian and Gotland cases, Swedish Nuclear Fuel and Waste Management Company (SKB) Technical Report, SKB TR 88-26 (1988). 
[33] D.M. Anderson, Smectite alteration, Swedish Nuclear Fuel and Waste Management Company (SKB) Technical Report, SKB TR 83-03 (1983).

[34] F. Benvegnu, A. Brondi and C. Polizzano, Natural analogues and evidence of long-term isolation capacity of clays occurring in Italy: contribution to the demonstration of geological disposal reliability of long-lived wastes in clay, Commission of the $\mathrm{Eu}-$ ropean Communities (CEC) Nuclear Science and Technology Report, EUR 11896 (1988).

[35] Y. Yusa, G. Kamei and T. Arai, Some aspects of natural analogue studies for assessment oflongterm durability of engineered barrier materials - recent activities at PNC Tokai, Commission of the European Communities (CEC) Nuclear Science and Technology Report, EUR 13014 (1991).

[36] L. Pérez del Villar, A. Delgado, E. Reyes, M. Pelayo, J.M. Fernández-Sler, J.S. Cózar, M. Tsige and A.J. Quejido, "Thermochemically induced transformations in Al-smectites: A Spanish natural analogue of the bentonite barrier behaviour in a radwaste disposa", Appl. Geochem., 20, pp. 2252-2282 (2005).

[37] M. Pelayo, E. García-Romero, M.A. Labajo and L. Pérez del Villar, "Occurrence of Fe-Mg-rich smectites and corrensite in the Morrón de Mateo bentonite deposit (Cabo de Gata region, Spain): A natural analogue of the bentonite barrier in a radwaste repository", Appl. Geochem., 26, pp. 11531168 (2011).

[38] R. Pusch, Settlement of canisters with smectite clay envelopes in deposition holes, Swedish Nuclear Fuel and Waste Management Company (SKB) Technical Report, SKB TR 86-23 (1986).

[39] L. Börgesson and Pusch, Interim report on the settlement test in Stripa, SKB Technical Report, TR 89-29, Swedish Nuclear Fuel and Waste Management Company, Stockholm (1989).

[40] R. Pusch, Copper-bentonite interactions, Swedish Nuclear Fuel and Waste Management Company (SKB) Technical Report, SKB TR 82-07 (1982).

[41] J.P. Simpson, Experiments on container materials for Swiss high-level waste disposal projects: part II,
Swiss National Cooperative for Radioactive Waste Management (Nagra) Technical Report, NTB 8401 (1984).

[42] C.F. Lee, A case history on long-term effectiveness of clay sealant, Commission of the European Communities (CEC) Nuclear Science and Technology Report, EUR 10671 (1986).

[43] T.E. Eriksen and A. Jacobsson, Diffusion of hydrogen, hydrogen sulphide and large molecular weight anions in bentonite, Swedish Nuclear Fuel and Waste Management Company (SKB) Technical Report, SKB TR 82-17 (1982).

[44] P. Vilks, D.B. Bachinski and T.T. Vandergraaf, "The role of particulates in radionuclide transport.", Proceedings of the 3rd International Symposium on Advanced Nuclear Energy Research, Mito City, Japan (1991).

[45] F. Rassineux, J.C. Petit and A. Meunier, "Ancient analogues of modern cement: calcium hydrosilicates in mortars and concretes from Gallo-Roman thermal baths of western France", J. Am. Ceramic Soc., 72, pp. 1026-1032 (1989).

[46] S.P. Jull and T.P. Lees, Studies of historic concrete, Commission of the European Communities (CEC) Nuclear Science and Technology Report, EUR 12972 (1990).

[47] G.M. Idorn and N. Thaulow, "Examination of 136 years old portland cement concrete", Cement Concrete Res., 13, pp. 739-743 (1983).

[48] J.A. Steadman, Archceological concretes as analogues, Commission of the European Communities (CEC) Nuclear Science and Technology Report, EUR 10671 (1986).

[49] I.G. McKinley, A.H. Bath, D. Berner, M. Cave and C. Neal, "Results of the Oman analogue study", Radiochim. Acta, 44/45, pp. 311-316 (1988).

[50] W.R. Alexander, R. Dayal, K. Eagleson, J. Eikenberg, E. Hamilton, C.M. Linklater, I.G. McKinley and C.J. Tweed, "A natural analogue of high $\mathrm{pH}$ cement pore waters from the Maqarin area of northern Jordan II: results of predictive geochemical calculations", J. Geochem. Explor., 46, pp. 133-146 (1992). 
[51] D. Read, Geochemical modelling of the Broubster natural analogue site, Caithness, Scotland, BGS Technical Report, WE/88/43 (1988).

[52] P.J. Hooker, "An overview and assessment of the British Geological Survey's research work on natural analogue studies in Great Britain", Radiochim. Acta, 52/53, pp. 341-347 (1991).

[53] P.J. Hooker, M. Ivanovich, A.E. Milodowski, T.K. Ball, A. Dawes and D. Read, Uranium migration at the South Terras mine, Cornwall, British Geological Survey (BGS) Technical Report, WE/89/13 (1989).

[54] D.A. Sverjensky, "Geochemical investigations of uranium mobility in the Koongarra ore deposit: a natural analogue for the migration of radionuclides from a nuclear waste repository", in: Alligator Rivers Analogue Project: Annual Report 1989-1990, P. Duerden, ed., Australian Nuclear Science and Technology Organisation, Sydney (1991).

[55] J.E. Cross, A. Haworth, P.C. Lichtner, A.B. MacKenzie, L. Moreno, I. Neretnieks, D.K. Nordstrom, D. Read, L. Romero, R.D. Scott, S.M. Sharland and C.J. Tweed, Testing models of redox front migration and geochemistry at the Osamu Utsumi mine and Morro do Ferro analogue study sites, Poços de Caldas, Brazil, Swedish Nuclear Fuel and Waste Management Company (SKB) Technical Report, SKB TR 90-21 (1990).

[56] N.A. Chapman, I.G. McKinley, M.E. Shea and J.A.T. Smellie, The Poços de Caldas Project: summary and implications for radioactive waste management, Swedish Nuclear Fuel and Waste Management Company (SKB) Technical Report, SKB TR 90-24 (1990).

[57] J. Bruno, J.E. Cross, J. Eikenberg, I.G. McKinley, D. Read, A. Sandino and P. Sellin, Testing of geochemical models in the Poços de Caldas analogue study, Swedish Nuclear Fuel and Waste Management Company (SKB) Technical Report, SKB TR 90-20 (1990).

[58] D.K. Nordstrom, J.A.T. Smellie and M. Wolf, Chemical and isotopic compositions of groundwaters and their seasonal variability at the Osamu
Utsumi and Morro do Ferro analogue study sites, Poc;os de Caldas, Brazil, Swedish Nuclear Fuel and Waste Management Company (SKB) Technical Report, SKB TR 90-15 (1990).

[59] J. Liu, J.W. Yu and I. Neretnieks, "Transport modelling in the natural analogue study of the Cigar Lake uranium deposit (Saskachewan, Canada)", J. Contam. Hydrol., 21, pp. 19-34 (1996).

[60] O. Landström and E. Tullborg, The influence of fracture mineral/groundwater interaction on the mobility of U, Th, REE and other trace elements, Swedish Nuclear Fuel and Waste Management Company (SKB) Technical Report, SKB TR 90-37 (1990).

[61] J. Suksi, T. Ruskeeniemi, A. Linberg and T. Jaakkola, "The distribution of natural radionuclides on fracture surfaces in Palmottu analogue study site in SW Finland", Radiochim. Acta, 52/53, pp. 367372 (1991).

[62] J.A.T. Smellie, A.B. MacKenzie and R.D. Scott, "An analogue validation study of natural radionuclide migration in crystalline rocks using uraniumseries disequilibrium studies", Chem. Geol., 55, pp. 233-254 (1986).

[63] L. Pérez del Villar, P. Pelayo, J.S. Cózar, B. Cruz, J. Pardillo, E. Reyes, E. Caballero, A. Delgado, R. Nuñez, M. Ivanovich and S.E. Hasler, "Mineralogical and geochemical evidence of the migration/retardation processes of $U$ and $T h$ in fracture fillings from the El Berrocal granite site (Spain)", J. Contam. Hydrol., 26, pp. 45-60 (1997).

[64] D. Cui and T. Eriksen, "Fracture-filling minerals as uranium sinks and sources, a natural analogue study at Palmottu, Finland", Radiochim. Acta, 88, pp. 751-755 (2000).

[65] C. Pomiès, B. Hamelin, J. Lancelot and R. Blomqvist, "207 $\mathrm{Pb} /{ }^{206} \mathrm{~Pb}$ and ${ }^{238} \mathrm{U} /{ }^{230} \mathrm{Th}$ dating of uranium migration in carbonate fractures from the Palmottu uranium ore (southern Finland)", Appl. Geochem., 19, pp. 273-288 (2004).

[66] M.T. Crespo, L. Pérez del Villar, A.J. Quejido, M. Sánchez, M. Cózar and J.S. Fernández-Díaz, "Useries in $\mathrm{Fe}$-U-rich fracture fillings from the oxidised cap of the "Mina Fe" uranium deposit (Spain): im- 
plications for processes in a radwaste repository", Appl. Geochem., 18, pp. 1251-1266 (2003).

[67] A.J. Quejido, L. Pérez del Villar, J.S. Cózar, M. Fernández-Díaz and M.T. Crespo, "Distribution of trace elements in fracture fillings from the "Mina $\mathrm{Fe}^{\prime}$ uranium deposit (Spain) by sequential leaching: implications for the retention processes", Appl. Geochem., 20, pp. 487-506 (2005).

[68] P.J. Hooker, A.B. MacKenzie, R.D. Scott, I. Ridgway, I.G. McKinley and J.M. West, A study of natural and long term $\left(10^{3}-10^{4}\right.$ year) elemental migration in saturated clays and sediments, part III, Commission of the European Communities (CEC) Radioactive Waste Management Series, EUR 10788/2 (1985).

[69] R.D. Scott, A.B. MacKenzie, Y.A., Ben-Shabab, P.J. Hooker and C.M. Houston, "Uranium transport and retardation at the Needle's Eye natural aalogue site, southwest Scotland", Radiochim. Acta, 52/53, pp. 357-365 (1991).

[70] C. Menet, M.T. Ménager and J.C. Petit, "Migration of radioelements around the new nuclear reactors at Olko: Analogies with a high-level waste repository", Radiochim. Acta, 58/59, pp. 395-400 (1992).

[71] U. Noseck, Th. Brasser,P. Rajlich, A. Laciok and M. Hercik, "Mobility of uranium in tertiary argillaceous sediments - a natural analogue study", Radiochim. Acta, 92, pp. 797-803 (2004).

[72] R.J. Cornett, J. Fabryka-Martin, J.J. Cramer, H.R. Andrew and V.T. Koslowsky, ${ }^{36} \mathrm{Cl}$ production and mobility in the Cigar Lake uranium deposit", Nucl. Instrum. Methods in Phys. Res. B, 268, pp. 11891192 (2010).

[73] J. Suksi, T. Ruskeeniemi and L. Saarinen, "Selective extractions in uranium migration studies - findings from a natural analogue study at Palmottu, southern Finland", J. Contam. Hydrol., 21, pp. 47-58 (1996).

[74] S. Krishnaswami, W.C. Graustein and K.K. Turekian, "Radium, thorium and radioactive lead isotopes in groundwaters: Application to the in situ determination of adsorption-desorption rate constants and retardation factors", Water Resor. Res., 18, pp.
1633-1675 (1982).

[75] I.G. McKinley and W.R. Alexander, "Assessment of radionuclide retardation: uses and abuses of natural analogue studies", J. Contam. Hydrol., 13, pp. 249-259 (1993).

[76] I. Neretnieks, "Diffusion in the rock matrix: an important factor in radionuclide migration?", J. Geophy. Res., 85, pp. $4379-4397$ (1980).

[77] N.L. Jefferies, "Long-term solute diffusion in a granite block immersed in sea water", in: Natural Analogues in Radioactive Waste Disposal, B. Côme and N.A. Chapman, eds, pp. 249-260, Graham \& Trotman, London (1987).

[78] P. Pinto Coelho, "Element distribution across veins in the East Bull Lake gabbro anorthosite layered intrusion, Algoma District, Ontario. - an evaluation of matrix diffusion", in: Natural Analogues in Radioactive Waste Disposal, B. Côme and N.A. Chapman, eds, pp. 261-274, Graham \& Trotman, London (1987).

[79] W.R. Alexander, R.D. Scott, A.B. MacKenzie and I.G. McKinley, "A natural analogue study of radionuclide migration in a water conducting fracture in crystalline rock", Radiochim. Acta, 44/45, pp. 283-289 (1988).

[80] W.R. Alexander, A.B. MacKenzie, R.D. Scott and I.G. McKinley, Natural analogue studies in crystalline rock: the influence of water-bearing fractures on radionuclide immobilization in a granitic rock repository, Swiss National Cooperative for Radioactive Waste Management (Nagra) Technical Report, NTB 87-08 (1990).

[81] W.R. Alexander, I.G. McKinley, A.B. MacKenzie and R.D. Scott, "Verification of matrix diffusion by means of natural decay series disequilibria in a profile across a water conducting fracture in granitic rock", Scientific Basis for Nuclear Waste Management, XIII, pp. 567-576 (1990).

[82] M. Mazurek, A. Gautschi and S. Vomvoris, "Deriving input data for discrete transport models from deep borehole investigations: an approach for crystalline rocks", in: IAEA/CEC International Symposium on Geological Disposal of Spent Fuel, High 
Level and Alpha-Bearing Waste, Antwerp., International Atomic Energy Agency, Vienna (1992).

[83] R. Blomqvist, T. Jaakkola, H. Niini and L. Ahonen, The Palmottu analogue project: progress report 1990, Geological Survey of Finland, Nuclear Waste Disposal Research Report, YST-73 (1991).

[84] M.J. Heath, M. Montoto, A.R. Rey, V.G. Ruiz de Argandoña and N. Menendez, "Rock matrix diffusion as a mechanism of raidonuclide retardation: A natural analogue study of El Berrocal Granite, Spain", Radiochim. Acta, 58/59, pp. 379-384 (1992).

[85] J. Suksi, T. Ruskeeniemi and K. Rasilainen, "Matrix diffusion - Evidences from natural analogue studies at Palmottu in SW Finland", Radiochim. Acta, 58/58, pp. 385-393 (1992).

[86] M. Montoto, A. Rodriguez Rey, V.G. Ruiz de Argandona, B. Menendez and M.J. Heath, Natural analogues and microstructural studies in relation to radionuclide retardation by rock matrix diffusion in grani tes: final report, CEC Radioactive Waste Management Series, Commission of the European Communities, Luxembourg (1991).

[87] M. Ivanovich, R. Blomqvist and S.K. Frape, "Rock/ water interaction study in deep crystalline rocks using isotopic and uranium series raidonuclide techniques", Radiochim. Acta, 58/59, pp. 401-408 (1992).

[88] L. Jokelainen, M. Markovaara-Koivisto, D. Read, A. Lindberg, M. Siitari-Kauppi and K.H. Hellmuth, "Understanding uranium behaviour at the Askola uranium mineralization", Radiochim. Acta, 98, pp. 743-747 (2010).

[89] T. Nohara, Y. Ochiai, T. Seo and H. Yoshida, "Uranium-series disequilibrium studies in the Tono uranium deposit, Japan", Radionchim. Acta, 58/59, pp. 409-413 (1992).

[90] D. Andretta, M. Voltaggio, A. Taddeucci and C. Polizzano, "Disequilibrium of uranium, thorium and radium isotope in Pliocenic clays", Radiochim. Acta, 58/59, pp. 415-421 (1992).

[91] M. Ivanovich, J.H. Tellam, G. Longworth and J.J. Monaghan, "Rock/water interaction timescales involving $\mathrm{U}$ and $\mathrm{Th}$ isotopes in a Permo-Triassic sandstone", Radiochim. Acta, 58/59, pp. 423432 (1992).

[92] D. Arcos, L. Pérez del Villar, J. Bruno and C. Domènech, "Geochemical modelling of the weathering zone of the "Mina Fe" U deposit (Spain): A natural analogue for nuclear spent fuel alteration and stability processes in radwaste disposal", Appl. Geochem., 23, pp. 807-821 (2008).

[93] P. Vilks, J.J. Cramer, D.B. Bachinski, D.C. Doern and H.G. Miller, "Studies of colloids and suspended particles, Cigar Lake uranium deposit, Saskachewan, Canada", Appl. Geochem., 8, pp. 605-616 (1993).

[94] N. Miekeley, H. Coutinho de Jesus, C.L. Porto da Silveira and C. Degueldre, "Chemical and physical characterisation of suspended particles and colloids in waters from the Osamu Utsumi mine and Morro do Ferro analogue study sites, Poços de Caldas, Brazil", J. Geochem. Explor., 45, pp. 409-438 (1992).

[95] R. Edghill and B.G. Davey, "Colloids in Koongarra groundwater", in: Alligator Rivers Analogue Project: progress report May 1988 - August 1988, P. Duerden, ed., Australian Nuclear Science and Technology Organisation, Sydney (1988).

[96] T. Seo, "Uranium distribution in the colloidal and solute phases at the Koongara uranium deposit", in: Alligator Rivers Analogue Project: second annual report 1989-1990, P. Duerden, ed., Australian Nuclear Science and Technology Organisation, Sydney (1991).

[97] M.H. Baik, S.Y. Lee and Y. Roh, "Roles and importance of microbes in the radioactive waste disposal", J. Korean Radioact. Waste Soc., 7(1), pp. 63-72 (2009).

[98] K. Pedersen, Microbial processes in radioactive waste disposal, Swedish Nuclear Fuel and Waste Management Company (SKB) Technical Report, SKB TR 00-04 (2000).

[99] S.A. Haveman and K. Pedersen, "Microbially mediated redox processes in natural analogues for radioactive waste", J. Contam. Hydrol., 55, pp. 161- 
174 (2002)

[100] P.S. Hahn, J.E. Kuh, C.H. Kang, C.K. Park, Y.M. Lee, M.H. Baik, P.K. Lee, W.J. Cho, J.O. Lee, D.K. Keum, Y.H. Cho, J.H. Ha, T.W. Hwang and C.H. Chung, Technology Development for HLW Disposal - Technology Development for HLW Disposal System Evaluation, Korea Atomic Energy Research Institute (KAERI) Report, KAERINEMAC/RR-170/96 (1996).

[101] C.L. Kim and H.W. Chang, "Limitation of natural analogue studies on rock matrix diffusion", J. Korean Soc. Groundwater Environ., 1(2), pp. 100104(1994).

[102] J.B. Park, J.W. Park, C.L. Kim, S.E. Yang and S.B. Lee, "A natural analog study on the coverlayer performance for near-surface LILW disposal by considering the tomb of historical age", J. Korean Radioact. Waste Soc., 3(4), pp. 279-291 (2005).

[103] M.S. Lee and S.W. Kim, "Uranium distribution patterns and U-mineral in the U-bearing coaly slate of Ogcheon system", J. Korean Inst. Mining Geol., 18(2), pp. 135-138 (1985).

[104] S. Yun, "Mineralogical and geochemical studies of uranium deposits of the Okchon group in southwestern district off Taejon, Korea", J. Korean Inst. Mining Geol., 17(4), pp. 289-298 (1984).

[105] D. Shin and S. Kim, "Geochemical characteristics of black slate and coaly slate from the uranium deposit in Deokpyeong area", Econ. Environ. Geol., 44(5), pp. 373-386 (2001).

[106] J.I. Chung, M.S. Lee and C.K. Na, "Geochemical study on the uranium anomaly around the Shinbo talc mine (I) - In the light of hydrochemical properties", Econ. Environ. Geol., 31, pp. 101-110 (1998).

[107] C.K. Na, H.Y. Park and H.J. Park, "Geochemical study on the uranium anomaly around the Shinbo talc mine (II) - In the light of isotopic characteristics", Econ. Environ. Geol., 33, pp. 367-377 (2000).

[108] C.O. Choo, "Characteristics of uraniferous minerals in Daebo granite and significance of mineral species", J. Miner. Soc. Korea, 15, pp. 11-21 (2002).

[109] S. Y. Lee and M.H. Baik, "Uranium and other trace elements' distribution in Korean granite: implications for the influence of iron oxides on uranium migration", Environ. Geochem. Health, 31, pp. 413-420 (2009).

[110] S.Y. Lee, M.H. Baik and Y.B. Lee, "Adsorption of uranyl ions and microscale distribution of $\mathrm{Fe}$ bearing mica", Appl. Clay Sci., 44, pp. 259-264 (2009).

[111] S.Y. Lee, M.H. Baik, Y.J. Lee and Y.B. Lee, "Adsorption of $\mathrm{U}(\mathrm{VI})$ ions on biotite from aqueous solutions", App. Clay Sci., 46, pp. 255-259 (2009).

[112] M.H. Baik, S.P. Hyun, W.J. Cho and P.S. Hahn, "Contribution of minerals to the sorption of $\mathrm{U}(\mathrm{VI})$ on granite", Radiochim. Acta, 92, pp. 663-669 (2004).

[113] B.W. Cho, C.O. Choo, M.S. Kim, Y.J. Lee, U. Yun and B.D. Lee, "Uranium and radon concentration in groundwater near the Icheon granite", J. Eng. Geol., 21(3), pp. 259-269 (2011).

[114] D.H. Jeong, M.S. Kim, B.K. Ju and T.S. Kim, "Distribution characteistics of uranium and radon concentration in groundwaters of provinces in Korea", J. Soil Groundwater Environ., 16(6), pp. 143-149 (2011).

[115] Nagra, KRISTALLIN-I: safety assessment report, Swiss National Cooperative for Radioactive Waste Management (Nagra) Technical Report, NTB 9323 (1994).

[116] SKB, Treatment and final disposal of nuclear waste, Swedish Nuclear Fuel and Waste Management Company (SKB), SKB RD and D Programme 92 (1992).

[117] PNC, Research and de elopment on geological disposal of high-level radioactive waste, Power Reactor and Nuclear Fuel Development Corporation of Japan (PNC) Report, TN1410(930059) (1992).

[118] M.L. Wilson, J.H. Gauthier, R.W. Bernard, G.E. Barr and H.A. Dockery, Total system performance assessment at Yucca Mountain - SNL second iteration (TSPA-1993), Sandia National 